\title{
Chapter 13 \\ Nutrient Dynamics in Decomposing Dead Wood in the Context of Wood Eater Requirements: The Ecological Stoichiometry of Saproxylophagous Insects

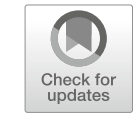

\author{
Michał Filipiak
}

\begin{abstract}
Dead wood is rich in sugars and can serve as an energy source when digested, but it lacks other nutrients, preventing the growth, development, and maturation of saproxylophages (saproxylic organisms that consume dead wood at any stage of decomposition). Split into atoms, sugars only serve as a source of carbon, hydrogen, and oxygen, thereby providing insufficient nutrition for saproxylophages and for their digestive tract symbionts, despite the ability of certain symbionts to assimilate nitrogen directly from the air. Ecological stoichiometry framework was applied to understand how nutritional scarcity shapes saproxylophage-dead wood interactions. Dead wood is 1-3 orders of magnitude inadequate in biologically essential elements ( $\mathrm{N}, \mathrm{P}, \mathrm{K}, \mathrm{Na}, \mathrm{Mg}, \mathrm{Zn}$, and $\mathrm{Cu}$ ), compared to requirements of its consumers, preventing the production of necessary organic compounds, thus limiting saproxylophages' growth, development, and maintenance. However, the wood is nutritionally unstable. During decomposition, concentrations of the biologically essential elements increase promoting saproxylophage development. Three mechanisms contribute to the nutrient dynamics in dead wood: (1) C loss, which increases the concentration of other essential elements, (2) N fixation by prokaryotes, and (3) fungal transport of outside nutrients. Prokaryotic $\mathrm{N}$ fixation partially mitigates the limitations on saproxylophages by the scarcity of $\mathrm{N}$, often the most limiting nutrient, but co-limitation by seven elements $(\mathrm{N}, \mathrm{P}, \mathrm{K}, \mathrm{Na}, \mathrm{Mg}, \mathrm{Zn}$, and $\mathrm{Cu}$ ) may occur. Fungal transport can shape nutrient dynamics early in wood decay, rearranging extremely scarce nutritional composition of dead wood environment during its initial stage of decomposition and assisting saproxylophage growth and development. This transport considerably alters the relative and total amounts of non-C elements, mitigating also nutritional constraints experienced by saproxylophages inhabiting such nutritionally enriched wood during
\end{abstract}

M. Filipiak (殴

Institute of Environmental Sciences, Jagiellonian University, Kraków, Poland

This is a U.S. government work and its text is not subject to copyright protection in the 429 United States; however, its text may be subject to foreign copyright protection 2018 M. D. Ulyshen (ed.), Saproxylic Insects, Zoological Monographs 1,

https://doi.org/10.1007/978-3-319-75937-1_13 
later stages of decomposition. Additionally, $\mathrm{C}$ losses during later decomposition stages may further change non-C element concentrations beyond fungal enrichment. More detailed studies of the short-term nutrient dynamics in dead wood relative to the nutritional requirements of saproxylophages are needed to understand decomposition process and nutrient cycling in ecosystems. These studies should include a wide array of elements that may be limiting for saproxylophages (e.g., $\mathrm{P}, \mathrm{Na}, \mathrm{K}, \mathrm{Mg}$, $\mathrm{Zn}$, and $\mathrm{Cu}$ in addition to commonly studied $\mathrm{N}$ ). Studies on nutrient dynamics in dead wood should discuss obtained data in the context of nutritional needs of saproxylophages. To allow for this, data on multielemental ecological stoichiometry of saproxylophages of various taxa, inhabiting different wood species in various geographical locations, are needed.

\subsection{Background: Nutritional Scarcity in Dead Wood and Why It Matters}

Wood is composed of approximately 90-99\% cellulose, hemicelluloses, and lignin (Parkin 1940; Pettersen 1984) and consists of 50\% C, 44\% O, and 6\% $\mathrm{H}$ as well as trace amounts of other elements (Pettersen 1984). In temperate zones, elements other than $\mathrm{C}, \mathrm{H}, \mathrm{O}, \mathrm{N}$, and $\mathrm{S}$ may comprise approximately $0.1-0.6 \%$ of wood, but tropical wood may be more nutritious, containing up to 5\% ash (Ragland et al. 1991; Pettersen 1984). Additionally, wood may consist of approximately $0.08-0.2 \%$ of N (Meerts 2002) and 0.003-0.03\% of P (Pettersen 1984; Meerts 2002), which are extremely low concentrations that are insufficient for insects and other arthropods (they have one- to threefold higher $\mathrm{N}$ and $\mathrm{P}$ concentrations in their bodies (Fagan et al. 2002; Schneider et al. 2010; Filipiak and Weiner 2014; Filipiak 2016); see Sterner and Elser (2002) and Elser et al. (2000a, b) for discussions on how such nutritional imbalances may limit organisms and influence ecosystems). In dead wood, $C: N$ and $C: P$ ratios may be as high as 6500/7500 and 54,500/150,000 (dry mass ratio/molar ratio), respectively, which indicates severe nutritional scarcity for potential consumers (Filipiak and Weiner 2014; Filipiak et al. 2016). Therefore, the chemical composition of dead wood differs from that of other plant tissues because it is extraordinarily rich in $\mathrm{C}, \mathrm{H}$, and $\mathrm{O}$ atoms but scarce in other elements and thus extremely nutritionally unbalanced for its potential consumers. In this context, the growth and development of dead wood-eating beetles may be co-limited by the scarcity of non-sugar nutrients in dead wood, including essential bioelements such as N, P, K, Na, Mg, Zn, and Cu (Filipiak and Weiner 2014, 2017a; Filipiak et al. 2016). The limitations imposed by differences between nutritional demand (the nutritional needs of growing organisms) and supply (the availability of the nutrients required in an environment) can determine the fitness of an organism and may influence its ecological interactions (Haack and Slansky 1987; Sterner and Elser 2002; Pokarzhevskii et al. 2003; Cherif 2012; Kaspari and Powers 2016). A mismatch between the nutritional composition of food and the requirements of a consumer can limit the growth and development of the consumer even when 
potential foods are available in excess (Haack and Slansky 1987; Sterner and Elser 2002), which raises the following question: How do wood-eating insects obtain the nutrients required for growth and development?

The nutritional scarcity of dead wood may cause supplementary carnivory, which is observed among saproxylophages (Stokland et al. 2012), and cannibalism is a special kind of predation exhibited by some of saproxylic species. For example, larvae of the large wood-boring beetle genus Monochamus are highly carnivorous and will rapidly devour each other (Soper and Olson 1963), and these insects also feed on bark beetles they encounter within dead wood (Dodds et al. 2001). Furthermore, Thorne and Kimsey (1983) observed Nasutitermes termites feeding on a dead boa constrictor, a three-toed sloth, and a turtle, and in all cases, the termites had constructed carton foraging galleries over portions of the remains, beneath which feeding took place. Interestingly, carrion feeding was observed only during the dry season, when the demand for nutrients is highest due to the production of thousands of winged and reproductive adults. Termites are also known to feed on dead insect larvae and other corpses encountered while foraging in wood (Thorne and Kimsey 1983, and examples therein), which most notably includes cannibalizing dead (and in some cases living) nestmates, a behavior that is apparently exhibited by all termites (Wilson 1971). Apart from these examples, there are a number of saproxylophagous insects that apparently feed exclusively on dead wood and are able to survive and thrive on this low-quality food source (Wallace 1953; Hanula 1996; Grove 2002; Nadeau et al. 2015; Ulyshen 2016). How is this possible?

The activity of digestive tract symbionts is known to play a role in balancing the diet of insects that utilize suboptimal plant resources as their food (Ljungdahl and Eriksson 1985; Martin et al. 1991; Dillon and Dillon 2004; Douglas 2009), and in this context, xylophagous insects are believed to survive and thrive utilizing polysaccharides as either a direct food source or as a resource for their digestive tract symbionts (Mansour 1934; Parkin 1940; Martin 1983; Watanabe and Tokuda 2010). However, according to the law of the conservation of mass, this is insufficient because the constituent atoms of nutrients cannot be created by organisms from the available biomass. Therefore, the elemental composition of wood limits the available nutrients, although symbionts are able to increase the digestibility of woody matter and synthesize important organic compounds from nutrients furnished by dead wood (Ljungdahl and Eriksson 1985; Martin et al. 1991; Douglas 2009). Indeed, it has been suggested that the ability to feed on cellulose is rarely advantageous for insects (Martin et al. 1991). Polysaccharides and lignin, even when split into atoms, are a source of only three chemical elements $(\mathrm{C}, \mathrm{H}$, and $\mathrm{O})$. This is not enough to enable the growth, development, and functioning of a living organism. Even considering the ability of symbionts to directly assimilate the fourth essential element $(\mathrm{N})$ from the atmosphere, this is still not enough, since a source of other micronutrients is required to synthesize physiologically essential organic molecules (e.g., RNA, metalloproteins, enzymes, structural proteins, phospholipids, nucleotides, and vitamins). Therefore, wood alone may not be an appropriate food source for many saproxylic insects, even considering the activity of their digestive tract symbionts. 
As reviewed by Swift and Boddy (1984), the colonization of dead wood by most arthropods requires, or is at least strongly favored by, prior microbial conditioning. Even species in close symbiotic relationships with microbes capable of breaking down wood often prefer wood that is already infested by fungi and other microorganisms (Kovoor 1964; Gentry and Whitford 1982). For example, Becker (1965) found that termites in dry wood consume approximately twice as much wood decayed by brown rot fungi as nondecayed wood, and after 18 months, colonies feeding on decayed wood were approximately five times larger than their counterparts in nondecayed wood. Research by Smythe et al. (1971) found the subterranean termite Reticulitermes flavipes (Kol.) to exhibit a similar preference for decayed wood, and Hendee (Hendee 1935) found Zootermopsis termites feeding on pine wood containing fungi to be healthier than those feeding on uninfested wood. According to Swift and Boddy (1984), there are four primary ways by which microbial activity may favor colonization and feeding by wood-dwelling arthropods: (1) production of attractant substances, (2) softening of wood through enzymatic activity, (3) destruction of allelopathic substances against wood-dwelling arthropods, and (4) improving the nutritional quality of the resource. Indeed, dead wood is not nutritionally stable, and microbial activity is responsible for the nutritional enrichment of dead wood (Filipiak et al. 2016). Nutritionally scarce dead wood may be highly enriched in nutrients during the first few years of decomposition, allowing saproxylophages to meet their nutritional needs (Filipiak and Weiner 2014; Filipiak et al. 2016). It has been suggested that dynamic changes in the nutritional composition of dead wood occur during the larval development of saproxylic beetles that promote their growth, development, and maturation (Filipiak and Weiner 2017a). These changes may be caused by decomposing fungi (Filipiak et al. 2016) and protists (Fukasawa et al. 2017).

As wood decomposes, it is colonized by a succession of microorganisms and saproxylic insects (Grove 2002), the majority of which are represented by three groups: beetles (Coleoptera), midges and flies (Diptera), and termites and cockroaches (Blattodea) (Hanula 1996; Grove 2002; Stokland et al. 2012) with beetles being among the first colonists of dead wood (Nadeau et al. 2015). Saproxylophages are also represented by butterflies (Lepidoptera), true bugs (Heteroptera), and hymenopterans (Hanula 1996; Stokland et al. 2012; Seibold et al. 2014). From these, beetles and termites have been studied most (see literature reviews by Grove 2002; Ulyshen 2016; Nadeau et al. 2015; Hanula 1996). To date, few data have been published on the nutrient dynamics of decaying wood associated with the nutritional needs of saproxylophages, and only three species of insects (beetles) have served as model organisms: Stictoleptura rubra (L.), Arhopalus rusticus (L.) (Coleoptera, Cerambycidae) and Chalcophora mariana (L.) (Coleoptera, Buprestidae) (Filipiak and Weiner 2014, 2017a; Filipiak et al. 2016).

This chapter will be presented within the framework of ecological stoichiometry (or biological stoichiometry), i.e., the study of the balance of energy and multiple chemical elements in ecological interactions (Sterner and Elser 2002; Filipiak and Weiner 2017b; Cherif et al. 2017). Ecological stoichiometry considers how the chemical composition of organisms differs from that of their food and the 
consequences of these differences for growth and development (Fraústo da Silva and Williams 2001; Sterner and Elser 2002). This concerns the organic chemistry of life but, in particular, the chemical elements that are the basic building blocks of all living matter from bacteria to wales. It is impossible to understand the nutritional constraints on the growth and development of individual organisms, colonies, and populations without considering these elements (see Cherif et al. 2017 for a discussion on how ecological stoichiometry may improve this understanding). Despite their diversity and complexity, all molecules, cells, tissues, organisms, and populations are composed of the atoms of approximately 25 elements and are maintained through the use of energy (Fraústo da Silva and Williams 2001; Sterner and Elser 2002; Kaspari and Powers 2016). Moreover, all are composed of specific sets of atoms selected from the environment in proportions required to create the organic molecules that form the bodies of organisms, which are built according to specific "elemental recipes" and thus must maintain "elemental" or "stoichiometric" homeostasis. Therefore, the active regulation of elemental body stoichiometry (proportions of atoms) is an essential trait of all organisms (Sterner and Elser 2002; Jeyasingh et al. 2017). In this context, the law of the conservation of mass predicts that the atoms of the approximately 25 elements composing all living things cannot be created from nothing. During growth and development, organisms achieve not only their final adult shape but also the size, condition, and fertility necessary for reproductive success. Adult bodies are fully formed, so their functionality is primarily limited by energy levels and, to a lesser degree, the availability of specific organic compounds (e.g., fatty acids and amino acids) and physiologically important ions such as K, Na, Mg, and Ca (Slansky and Rodriguez 1987; Cohen 2003). However, the ability to form a fully functional adult body may depend on the availability of body-building nutrients during the juvenile growth stages (Slansky and Rodriguez 1987; Sterner and Elser 2002). Thus, the growth and development of an organism may be compromised when food sources are nutrient limited, so adult fitness may be affected when deficiencies occur during the juvenile stage. Herbivores and detritivores rely on diets that are rich in energy but scarce in the components used for development and maintenance (e.g., metalloproteins, phospholipids, and amino acids, i.e., molecules rich in N, P, S, and metals), so the development and growth of these organisms may be limited by food quality, which is defined by the availability of (1) the nutrients required for growth and development and (2) the energy needed to fuel the biochemical processes contributing to growth and development as well as movement and foraging or, more simply, any action undertaken by an organism (Sterner and Hessen 1994; Sterner and Elser 2002; Pokarzhevskii et al. 2003; Cherif 2012; Kaspari and Powers 2016). Accordingly, saproxylophages (organisms that consume dead wood at any stage of decomposition) experience extremely severe nutritional limitations because their food (dead wood) almost exclusively consists of polysaccharides and lignin and therefore lacks other nutrients (Filipiak and Weiner 2014, 2017a). Sterner and Elser (2002) comprehensively discussed the nutritional needs of organisms relative to $C: N: P$ stoichiometry, and more than these three extensively studied elements are needed to form the cells and bodies of organisms (Fraústo da Silva and Williams 2001; Kaspari and Powers 2016). The 
multielemental stoichiometry of saproxylophages, dead wood, and the fungi inhabiting the wood are considered in this chapter.

\subsection{Nitrogen Fixation in Dead Wood and Saproxylophage Nutrition}

Much attention has been given to the limiting effect of $\mathrm{N}$ scarcity on saproxylophages and the mechanisms underlying $\mathrm{N}$ dynamics in decomposing dead wood (e.g., Cowling and Merrill 1966; Swift et al. 1979; Roskoski 1980; Higashi et al. 1992; Varm et al. 1994; Vega and Blackwell 2005; Douglas 2009; Ulyshen 2015, 2016; Johnston et al. 2016). Herbivores and detritivores generally face $\mathrm{N}$ scarcity, which influences their fitness, consumer-driven nutrient cycling, and the fate of primary production in ecosystems (Elser et al. 2000b; Fagan et al. 2002; Sterner and Elser 2002; Martinson et al. 2008; Evans-White and Halvorson 2017). Dead wood is especially $\mathrm{N}$ scarce, but $\mathrm{N}$ may be utilized from external sources (Roskoski 1980; Douglas 2009; Ulyshen 2015). Two major mechanisms contributing to the $\mathrm{N}$ enrichment of wood have been suggested: transport in fungal hyphae and fixation from the air (Stenlid et al. 2008; Ulyshen 2015, 2016). The role of the transport of $\mathrm{N}$, as well as other nutritional elements, by fungi will be discussed in further detail since such transport seems to be an important factor for mitigating the general nutritional scarcity (of all nutrients and not just $\mathrm{N}$ ) of dead wood (Filipiak and Weiner 2014, 2017a; Filipiak et al. 2016). Therefore, I would like to briefly discuss only $\mathrm{N}$ fixation in this subsection. There are two types of $\mathrm{N}$-fixing organisms that may mitigate $\mathrm{N}$ scarcity in the dead wood consumed by saproxylophages: (1) organisms that inhabit the wood and may therefore directly enrich the dead wood environment (e.g., Ulyshen 2015; Roskoski 1980; Spano et al. 1982) and (2) organisms that inhabit the digestive tracts of saproxylophages and may therefore mitigate the $\mathrm{N}$ scarcity experienced by saproxylophages regardless of that in the external dead wood environment (e.g., Ulyshen 2015; Douglas 2009). Both types of $\mathrm{N}$-fixing organisms may play different roles in mitigating $\mathrm{N}$ scarcity for saproxylophages, and I will first focus on the first type (1) of organisms. Mycorrhizal fungi and $\mathrm{N}$-fixing bacteria deliver up to $80 \%$ of all the $\mathrm{N}$ acquired by plants in temperate and boreal forests (Baldrian 2017), and half of the bacterial isolates from living trees may be able to fix atmospheric N (Aho 1974). Similarly, N fixation by bacteria and translocation of $\mathrm{N}$ by mycelial networks during decomposition increase the $\mathrm{N}$ content in dead wood with approximately $2 \mathrm{~kg} \mathrm{~N}^{-}$fixed ha ${ }^{-1}$ per year, which is an important contribution to the $\mathrm{N}$ cycling in the whole ecosystem (Stenlid et al. 2008; Baldrian 2017). A recent study (Rinne et al. 2017) showed the major role of $N$ fixation in increasing the $\mathrm{N}$ content of dead wood during the late stage of decay in a Norway spruce-dominated forest; it accounted for $60 \%$ of the total $\mathrm{N}$ accumulation in the most decayed of the studied wood. It is known that $\mathrm{N}$-fixing organisms play an important role in $\mathrm{N}$ cycling in ecosystems, and the amounts of $\mathrm{N}$ that they fix have 
been estimated (Roskoski 1980; Spano et al. 1982; Ulyshen 2015; Baldrian 2017; Rinne et al. 2017). However, this knowledge is taken out of context, since it was not related to the nutritional needs of saproxylophages, and the degree to which the amount of $\mathrm{N}$ fixed by microorganisms contributes to balancing the diet of saproxylophages is not known. Therefore, despite knowing that bacteria may fix $1-2 \mathrm{~kg} \mathrm{~N} \mathrm{ha}^{-1}$ per year and that these amounts are comparable to inputs from precipitation and dry deposition (2-3 $\mathrm{kg} \mathrm{N} \mathrm{ha}^{-1}$ per year) (Ulyshen 2015), what these amounts mean for the nutritional needs of growing and developing saproxylophages is not understood. Future studies should take qualitative data on the $\mathrm{N}$ dynamics in dead wood into account since the quality of food may affect the growth, development, life histories, and fitness of consumers regardless of quantity (Sterner and Hessen 1994; Pokarzhevskii et al. 2003; Kaspari and Powers 2016; Filipiak and Weiner 2017b). The contribution of $\mathrm{N}$-fixing bacteria to the $\mathrm{N}$ dynamics in dead wood has been shown to be temperature dependent and may therefore vary with geographical region (Rinne et al. 2017), which should be considered in future studies. Considering the other type (2) of organisms, the microbial symbionts in arthropod guts have been proposed as important vectors contributing to the growth of their hosts as well as to nutrient cycling in ecosystems, with $\mathrm{N}$ fixation rates of $10-40 \mathrm{~kg} \mathrm{ha}^{-1}$ per year (ten times more than that of type 1 organisms) (Nardi et al. 2002). There is no doubt that $\mathrm{N}$-fixing symbiotic microbes contribute to the supplementation of termite diets with $\mathrm{N}$. Additionally, there is some scarce and nonconclusive evidence of similar diet supplementation mechanisms in woodboring beetles (Higashi et al. 1992; Nardi et al. 2002; Kneip et al. 2007; Ulyshen 2015). Microbial $\mathrm{N}$ fixation may account for $>60 \%$ of the $\mathrm{N}$ in the colonies of the termite Neotermes koshunensis (Shiraki) (Täyasu et al. 1994), but it is worth noting that there are species of saproxylophagous insects that naturally lack $\mathrm{N}$-fixing gut symbionts (e.g., Hylotrupes bajulus (L.), Cerambycidae) as well as insects that contain such symbionts but whose use of the provided $\mathrm{N}$ has been impossible to prove (Bridges 1981). Douglas (2009) stated that the nutritional significance of microbial $\mathrm{N}$ fixation for insects is uncertain because the product of $\mathrm{N}$ fixation by bacteria is ammonia, which is potentially toxic to insects but may be metabolizable by animals to a small degree. Since most insects lack the ability to assimilate ammonia, they must rely on sources of high-quality $\mathrm{N}$ compounds (e.g., fungal hyphae) even if they live in symbiosis with $\mathrm{N}$-fixing microorganisms (Vinet and Zhedanov 2010). In their review, Crotti et al. (2010) stated that there has, to date, been no clear demonstration of the function of the gut bacteria in ants feeding on $\mathrm{N}$-scarce diets. However, ants have been shown to utilize different types of $\mathrm{N}$-fixing organisms (other than $\mathrm{N}$-fixing bacteria) and may rely on $\mathrm{N}$ fixed from the air by ant-cultivated fungi (Pinto-Tomás et al. 2009). Nardi et al. (2002) noted that the range of arthropod taxa that harbor $\mathrm{N}$-fixing symbionts is not known and that only a limited number of reports have confirmed utilization of fixed $\mathrm{N}$ by the few insect taxa known to have these symbionts in their guts. It is possible that newly emerging symbionts of insects relying on sugar-based diets, i.e., acetic acid bacteria, could contribute to insect $\mathrm{N}$ metabolism or recycling, but this issue requires further investigation (Crotti et al. 2010). Symbiotic interactions between saproxylophagous 
insects and microorganisms are known in the vast majority of termites and cockroaches, but there are limited data on the contribution of $\mathrm{N}$-fixing organisms to balancing the diets of Coleoptera and Hymenoptera (e.g., Vinet and Zhedanov 2010; Kneip et al. 2007; Lilburn et al. 2001; Ulyshen 2015). Furthermore, the available knowledge has been obtained using termites as model arthropods (Nardi et al. 2002; Dillon and Dillon 2004). In a literature review on insect-mediated $\mathrm{N}$ dynamics in decomposing wood, Ulyshen (2015) presented evidence of $\mathrm{N}$ fixation in insects that included data on 66 taxa of wood-feeding insects, including both saproxylophages and those in living wood, from 51 publications. Of the 66 taxa considered, $55(83.3 \%)$ were termites; $10(15.2 \%)$ were beetles, and 1 taxon $(1.5 \%)$ was a wasp. Similarly, of the 51 publications reviewed, $42(82.3 \%)$ concerned termites, $8(15.7 \%)$ concerned beetles, and $1(2 \%)$ concerned a wasp. Considering that approximately 2600 species of termites (Bignell et al. 2011) and 357,000 species of beetles (Bouchard et al. 2009) are known, one could conclude that the knowledge of the symbiosis between saproxylophagous insects and $\mathrm{N}$-fixing organisms is strongly biased toward specific social isopteran taxa, whose symbiotic associations may differ from those of other insects, so this information should be applied to other insects with caution. As noted by Dillon and Dillon (2004), studies of termites and cockroaches have shown the extent to which microbes may contribute to balancing the diets of their insect hosts. However, the class Insecta is diverse, even if considering only saproxylophages, and there are groups of insects whose relationships with their microbiotas are undefined (Dillon and Dillon 2004; Nardi et al. 2002; Kneip et al. 2007) even if the specific groups of microbes inhabiting their guts are known (Baldrian 2017). Future studies should investigate the degree to which N-fixing organisms mitigate $\mathrm{N}$ scarcity in the food of the different taxonomical groups of insects that inhabit different ecosystems and feed on specific species of dead wood.

The knowledge gaps concerning both the types of microbes and the variations in the significance of their actions for saproxylophages should be considered in future research, which should explore the $\mathrm{N}$ dynamics in wood in the context of the life history, nutritional physiology, and fitness of wood consumers. This may be done using the multidimensional view of the ecological stoichiometry framework proposed by Reiners (1986) and postulated by Elser et al. (1996) and by Sterner and Hessen (1994) and described in detail in the book by Sterner and Elser (2002) [the ecological stoichiometry framework will be briefly introduced in Sect. 13.4, but for more detailed reviews, see, e.g., Sterner and Elser (2002), Hessen et al. (2013), Elser et al. (2000a), Moe et al. (2005), Klausmeier et al. (2008), Sardans et al. (2012), Lemoine et al. (2014), Sperfeld et al. (2016a, 2017), Filipiak and Weiner (2017b), Cherif et al. (2017)]. To elucidate the function that insects and their microbiota play in $\mathrm{N}$ cycling in ecosystems, future research should consider consumer-driven nutrient recycling $(C N R)$, in which the flow of matter through the food chain is regulated by the elemental body composition of species that compose particular links in the chain (for reviews on CNR, see, e.g., Elser and Urabe 1999 and Atkinson et al. 2016). 


\subsection{Nitrogen Is an Important, but Not the Only Important, Element: The Role of Dead Wood Enrichment During Decomposition in $\mathbf{P}$ and Other Non-C Elements}

Nitrogen is not the only physiologically important element, and co-limitation of the growth and development of animals by a set of elements that are scarce in food is more probable than limitation by a single or the most limiting element (Kaspari and Powers 2016; Filipiak and Weiner 2017b). Atoms of approximately 25 chemical elements are required to build an organism, and a shortfall in any can limit the development, performance, and fitness of an individual, thus altering population growth and, eventually, ecosystem function (Sterner and Elser 2002; Cherif 2012; Kaspari and Powers 2016; Fraústo da Silva and Williams 2001). To maintain stoichiometric homeostasis, growing individuals must collect specific proportions of atoms to form adult bodies according to a specific "elemental recipe" (Sterner and Elser 2002; Cherif 2012; Kaspari and Powers 2016; Jeyasingh et al. 2017), so their growth, development, and fitness are likely co-limited by a set of food-borne elements found in limited quantities (Kaspari and Powers 2016). This phenomenon has received limited attention in studies focused on the nutrient dynamics of decomposing wood (e.g., Swift et al. 1979; Boddy and Watkinson 1995; Laiho and Prescott 2004; Strukelj et al. 2017; Yuan et al. 2017), and although changes in the concentrations of elements during decomposition have been studied, they have not been related to the nutritional needs of saproxylophagous insects. Some studies have focused on long-term patterns of nutrient mineralization, mobilization, input, and accumulation (e.g., Swift et al. 1979; Boddy and Watkinson 1995; Laiho and Prescott 2004; Strukelj et al. 2017; Yuan et al. 2017), and their emphasis on C sequestration and nutrient availability in entire ecosystems leaves open the possibility of deeper investigation of the nutritional relationships between wood and saproxylophagous insects. These relationships may be central to the decomposition of dead wood and nutrient cycling in ecosystems (Chen and Forschler 2016).

Phosphorous is one of the most limiting elements for organisms feeding on dead plant matter, and this limitation is considerably mitigated by decomposing fungi (Filipiak 2016; Filipiak et al. 2016). Concentrations of P may be related to the amount of RNA in an organism (Sterner and Elser 2002). The growth rate hypothesis $(G R H)$ postulates that $\mathrm{P}$ concentrations, growth rates, and body sizes are positively correlated (Elser et al. 1996, 2000b; Sterner and Elser 2002; Elser and Hamilton 2007; Hessen et al. 2013), so organisms feeding on food with high $C: P$ and $N: P$ ratios relative to the required ratios experience reduced growth, reproductive output, and survival (Sterner and Hessen 1994; Sterner and Elser 2002; Elser and Hamilton 2007; Danger et al. 2013; Hessen et al. 2013). Additionally, P limitations can affect ecosystem functioning and result in decreased litter decomposition rates (Kaspari and Yanoviak 2008; Čapek et al. 2016; Liu et al. 2016; Purahong et al. 2016). However, $\mathrm{P}$ is not the only element that is scarce in wood and limiting for wood eaters. Therefore, co-limitations on the growth and development of consumers with access to a limited number of elements through their food should be considered 
(cf. Kaspari and Powers 2016; Jeyasingh et al. 2017). Our understanding of elemental limitations in heterotrophs in the sense of Liebig's law, by which only the most limiting nutrient shapes ecological interactions, is too simplistic. Rather, multielemental (or multi-resource if macronutrients are considered) co-limitation likely occurs and shapes these interactions (Marleau et al. 2015; Kaspari and Powers 2016; Sperfeld et al. 2016b; Wirtz and Kerimoglu 2016; Jeyasingh et al. 2017; Kaspari et al. 2017a, b; Welti et al. 2017) (see also Meunier et al. 2017 for context and discussion of the links between nutrient stoichiometry and organismal traits). However, only $C: N: P$ ratios have been extensively studied to date within the framework of ecological stoichiometry and mainly in aquatic ecosystems (see Filipiak and Weiner 2017b for review). Of the other elements, Na appears to be particularly important for organisms feeding on plant matter (both dead and living), and since $\mathrm{Na}$ is rare in plant tissues (including dead wood) but highly concentrated in the bodies of herbivores and detritivores, it may be one of the elements that co-limit the growth and development of organisms feeding on either dead or living plant matter (e.g., Kaspari and Powers 2016; Kaspari et al. 2017a, b; Filipiak et al. 2017). Indeed, the Na concentration in a host plant has been shown to be a factor shaping the life history and fitness of butterflies (Swanson et al. 2016). Furthermore, a recent analysis of the literature related to ecological stoichiometry shows that data about elements other than $\mathrm{C}, \mathrm{N}$, and $\mathrm{P}$ are scarce, especially for terrestrial ecosystems (see Filipiak and Weiner 2017b for review). Currently, many researchers continue to focus on $C: N: P$ stoichiometry (e.g., Sitters et al. 2017; Meunier et al. 2017; Welti et al. 2017; Zhang and Elser 2017; Cherif et al. 2017, but see Jeyasingh et al. 2017, which discusses shifts from single-nutrient models to more complex, multiplenutrient models that predict co-limitation), so future studies should fill this gap. Considering a larger number of limiting elements may elucidate the mechanisms that shape ecological interactions and the functioning of food webs (Chen and Forschler 2016; Filipiak 2016; Filipiak and Weiner 2017b), thus illuminating the multielemental nutritional limitations imposed on the growth and development of saproxylophagous insects that include $\mathrm{P}, \mathrm{N}, \mathrm{K}, \mathrm{Na}, \mathrm{Mg}, \mathrm{Zn}$, and $\mathrm{Cu}$ (Filipiak and Weiner 2017a).

\subsection{Ecological Stoichiometry of Dead Wood Eaters: An Elementary Approach to Balancing Energy and Matter}

Chemical elements are the most basic and fundamental building blocks of all living matter, which, despite the diversity and complexity of its structure, consists of the same approximately 25 chemical elements that are obtained and assimilated with the use of energy (Sterner and Elser 2002; Cherif 2012; Kaspari and Powers 2016). Ecological stoichiometry considers organisms as sets of atoms selected from the environment in proportions required to create organic molecules. In this context of 
elemental (stoichiometric) homeostasis, the active regulation of elemental body stoichiometry is an essential trait of individuals (Sterner and Elser 2002; Jeyasingh et al. 2017) that influences the functioning of individuals as well as their ecological interactions, resulting in changes in populations and affecting communities and ecosystems as well as global levels of organization (Sterner and Hessen 1994; Sterner and Elser 2002; Cherif 2012; Cherif and Loreau 2013; Hessen et al. 2013; Galbraith and Martiny 2015; Wilder and Jeyasingh 2016; Zhang et al. 2016; Jeyasingh et al. 2017). Every species has a unique composition of chemical elements that must be homeostatically maintained (heterotrophs show lower levels of variability than autotrophs; Sterner and Elser 2002), which is the basis of the concept of the multidimensional stoichiometric niche that may expand our current understanding of how various biotic and abiotic factors regulate the abundance and distribution of organisms and how organisms utilize, affect, and compete for resources in the environment (Gonzalez et al. 2017).

The most influential feature of the elements that affect fitness is that specific atoms cannot be transformed into other atoms by an organism during processing. However, organic compounds composed of these atoms are changeable, and they can be procured from food or by symbionts that inhabit the digestive tract. This feature is consistent with the law of the conservation of mass, meaning that every developing organism has access to only the building materials offered by its environment. For saproxylic insects, this material consists of a few elements available in excess (e.g., C, H, and $\mathrm{O}$ ) and others found in limited quantities (e.g., $\mathrm{P}, \mathrm{N}$, and $\mathrm{Na}$; Sterner and Elser 2002; Kaspari and Powers 2016).

A mismatch between the elemental composition of a food and the requirements of a consumer, even when food is available in excess, limits the growth and development of the latter (Fig. 13.1; Sterner and Hessen 1994; Elser et al. 2000b; Sterner and Elser 2002; Schade et al. 2003), so maintaining a balance between the supply and demand of the elements needed for growth is crucial for development. Consequently, wood eaters must manage a high threshold of stoichiometric mismatching between their tissues and their food (Sterner and Hessen 1994; Sterner and Elser 2002; Denno and Fagan 2003; Fagan and Denno 2004; Hessen et al. 2013; Filipiak and Weiner 2017b). Incompatibility between the nutritional composition (including the elemental composition) of food and the needs of a consumer may result in limited energy budgets, slow growth rates, and decreased fecundity and survivorship (see Filipiak and Weiner 2017b for review). In other words, stoichiometric mismatches negatively influence the fitness of a consumer and must be overcome, regardless of the total amount of food available.

Previous studies (Filipiak and Weiner 2014, 2017a; Filipiak et al. 2016) have concluded that (1) during larval development, saproxylophagous beetles are confronted with a severe nutritional imbalance that is not solely caused by the poor digestibility of their food but mainly by stoichiometric mismatch; (2) the degree of stoichiometric mismatch between xylophagous larvae and decaying dead wood declines during larval development; (3) the relative proportion of nutritional elements other than $\mathrm{C}$ in wood increases substantially during decomposition, most likely because of the importation of nutrients by fungal mycelia; (4) nutritional 


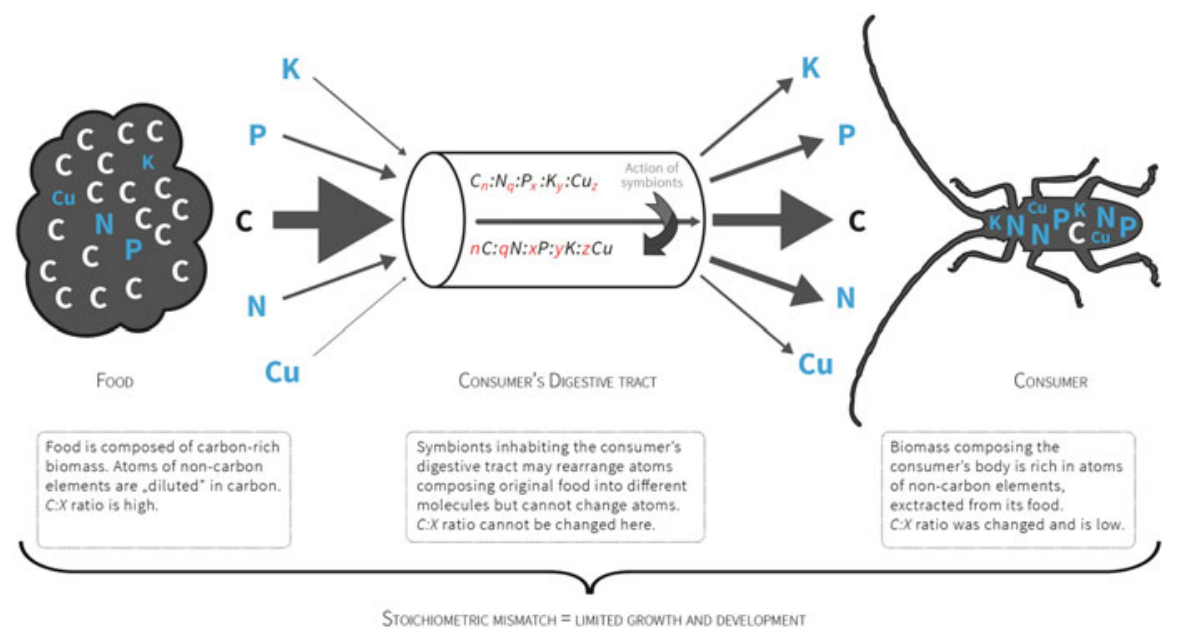

Fig. 13.1 Consumers that feed on nutritionally poor food (e.g., dead plant matter) consume a prepackaged ratio of atoms. For herbivores, detritivores, and saproxylophages, the food contains more $\mathrm{C}$ relative to other atoms, so these organisms must manage a diet with excess $\mathrm{C}$ that presents a stoichiometric imbalance that often limits their growth and development [consumer graphic source (changed): freevector.com; license: https://creativecommons.org/licenses/by-sa/4.0/]

elements that limit the development of xylophages include $\mathrm{N}, \mathrm{P}, \mathrm{K}, \mathrm{Na}, \mathrm{Mg}$, and $\mathrm{Cu}$; and (5) xylophage life history is shaped by elemental enrichment by fungal transfer of nutrients to dead wood. Particularly interesting and important for saproxylophage fitness are changes in the nutritional characteristics of dead wood that occur over time that correspond with saproxylophage larval development (i.e., the first several years of dead wood decay) and allow for saproxylophage growth, development, and maturation (Filipiak and Weiner 2017a). In this chapter, the nutrient dynamics of decomposing dead wood are discussed according to the nutritional needs of growing and developing saproxylophages under the framework of ecological stoichiometry, and the following section will explore (1) why the action of intestine tract symbionts does not solve the problem of an unbalanced diet; (2) how nutrient dynamics in decomposing dead wood may impact saproxylophage growth and development, thus influencing its fitness; and (3) how saproxylophage-fungi interactions can reduce stoichiometric mismatch, i.e., the limitations to growth and development experienced by a saproxylophage. 


\subsection{Limitations to the Growth and Development of Saproxylophages: What Symbionts Can and Cannot Do in Terms of Nutrient Dynamics}

Similar to their hosts, digestive tract symbionts are limited by the poor nutritional quality of their food, so stoichiometric mismatches and the corresponding limitations to growth and development affect both the saproxylophage and its symbionts. Digestive tract symbionts can improve the digestibility of food, supplement diets with $\mathrm{N}$, and synthesize organic compounds from the nutrients furnished by food, but the absolute content of every nutritional element, other than $\mathrm{N}$, processed by microbial symbionts cannot be increased by those microbes. The role of symbiotic organisms in insect nutritional ecology, as described by Douglas (2009), includes the following: (1) enrichment of $\mathrm{N}$-poor food via increases in the concentrations of $\mathrm{N}$ in nodules produced by cultivated fungi (termites), the use of $\mathrm{N}$ from insect waste compounds (symbionts: various bacteria and fungi; hosts: termites, cockroaches, and hemipterans), $\mathrm{N}$ fixation (symbionts: bacteria; hosts: termites, beetles, and flies) and the production of essential amino acids based on the available $\mathrm{N}$; (2) the production of vitamins and sterols based on available matter (symbionts: various bacteria and fungi; hosts: all herbivorous and detritivorous insects); (3) the generation of available nutrients through the digestion of nearly indigestible matter (symbionts: protists, bacteria and fungi; hosts: saproxylic insects and insects using other celluloserich diets); and (4) detoxification (symbionts: fungi; hosts: ants). However, every atom processed by digestive tract symbionts remains in the digestive tract and can be either assimilated or excreted. Furthermore, the rearrangement of available atoms into chemical compounds can change the digestibility of food and may ease excretion of some of the surplus $\mathrm{C}$, but it cannot influence the stoichiometric mismatches experienced by saproxylophages (Fig. 13.1). Thus, although digestive tract symbionts can alleviate $\mathrm{N}$ limitations for xylophages (as described in Sect. 13.2) and can make the diet more digestible, these symbionts cannot alleviate nutritional limitations independent of the digestibility of the diet, which is tied to the scarcity of elements other than $\mathrm{C}, \mathrm{H}, \mathrm{O}$, and $\mathrm{N}$.

\subsection{Nutritional Requirements of Saproxylophages Relative to the Nutritional Scarcity of Dead Wood}

Stoichiometric mismatch between the elemental composition of an organism and its food limits the organism's growth and development and negatively impacts its fitness, independent of the amount of food consumed; i.e., food quality may be limiting for the consumer regardless of quantity (Sterner and Elser 2002; Sterner and Hessen 1994; Cherif 2012; Kaspari et al. 2017a, b; Kaspari and Powers 2016; Pokarzhevskii et al. 2003; Denno and Fagan 2003; Fagan et al. 2002; Elser et al. 2000b; for review, see Filipiak and Weiner 2017b). In this context, I will calculate 
the index illustrating stoichiometric mismatch between various saproxylophages and different species of dead wood to relate the existing data on dead wood nutrient dynamics to the nutritional needs of saproxylophages. As a result, I will illustrate the meaning of the nutritional scarcity of dead wood for saproxylophages and the nutrient dynamics in decomposing wood.

The fundamental index in ecological stoichiometry is the threshold elemental ratio (TER), which allows the limiting effect imposed on an organism by stoichiometric mismatches to be calculated. The threshold elemental ratio is the lowest $C$ : other element atomic ratio in food at which the development of the consumer is not limited by the availability of $\mathrm{C}$ (i.e., energy) but is limited by the non-C element (Urabe and Watanabe 1992; Sterner and Elser 2002; Denno and Fagan 2003; Fagan and Denno 2004; Hessen et al. 2013). The basis for calculating the TER represents the requirement of the consumer for any non-C element during growth and development that is represented by utilizing the consumption rates, assimilation rates, and respiration rates of $\mathrm{C}$ and the non- $\mathrm{C}$ element of the consumer. Hence, both (1) the energy budget, measured as the $\mathrm{C}$ balance, and (2) the budget of any non- $\mathrm{C}$ element are considered.

The TER is understood as follows (Urabe and Watanabe 1992; Sterner and Elser 2002; Denno and Fagan 2003; Fagan and Denno 2004):

$$
\mathrm{TER}_{x}=\left(\mathrm{GGE}_{x} / \mathrm{GGE}_{C}\right) \times(C: X)_{i+1}
$$

where $\mathrm{GGE}_{x}$ is the gross growth efficiency of element $x, \mathrm{GGE}_{C}$ is the gross growth efficiency of carbon, $i$ is the trophic level, $C$ is the concentration of carbon, and $X$ is the concentration of element $x$.

If

$$
(C: X)_{i} \geq \mathrm{TER}_{x}
$$

then element $x$ may become a limiting factor for growth at trophic level $i+1$.

Following Hessen et al. (2013), the TER for any $C: X$ ratio, where $X$ is any element other than carbon, may be calculated as follows:

$$
\operatorname{TER}_{X}=\left\{A_{X} /\left[\left(I_{C} A_{C}-R_{C}\right) / I_{C}\right]\right\} \times(C: X)_{i+1},
$$

where $A_{X}$ and $A_{C}$ are the assimilation rates for elements $C$ and $X$, respectively, $I_{C}$ is the carbon ingestion rate, $R_{C}$ is the carbon respiration rate, and $(C: X)_{i+1}$ is the atomic ratio of $C: X$ in the body of the consumer.

However, in the case of herbivorous invertebrates, utilizing this index is technically impossible for certain elements. The gross growth efficiencies should be experimentally measured through laboratory feeding trials using growing animals. Such data are extremely scarce, particularly for elements other than N and P. For organisms that feed on extremely nutritionally poor food and present low growth rates and larval development that can take several years (e.g., wood eaters), obtaining all the necessary data is practically impossible. Thus, the TER index for invertebrates can only be estimated based on arbitrary assumptions (Fagan and 
Denno 2004; Frost et al. 2006; Doi et al. 2010). To allow for the identification of multiple elements that co-limit the development of an organism and facilitate comparisons between various taxa, habitats, food, and life histories, the trophic stoichiometric ratio (TSR) was developed, which is a simplified version of the TER that solely utilizes the elemental composition data of an organism and its food and does not require feeding experiments (Filipiak and Weiner 2017a). The TSR is based on the following relationship:

$$
(C: X)_{i} /(C: X)_{i+1} \geq \mathrm{GGE}_{x} / \mathrm{GGE}_{C}
$$

The minimum balanced ratio of $\mathrm{GGE}_{x} / \mathrm{GGE}_{C}$ can be estimated as $1 / 0.25=4$ assuming that $75 \%$ of the consumed carbon is released as $\mathrm{CO}_{2}$ while the other consumed elements are incorporated with $100 \%$ efficiency. Hence, it is conservatively assumed that for $(C: X)_{i} /(C: X)_{i+1} \geq 4.0$, the element $x$ may impose a constraint on growth (Filipiak and Weiner 2017a). Therefore, the TSR is calculated as follows:

$$
\operatorname{TSR}_{x}=(C: X)_{\text {food }} /(C: X)_{\text {consumer }}
$$

where $C$ is the concentration of carbon and $X$ is the concentration of element $x$.

$\mathrm{A} \mathrm{TSR}_{x} \geq 4$ indicates a possible limitation on the growth and development of an organism caused by the scarcity of element $X$ in its food; the higher the TSR value, the more severe the limiting effect. The TSR is not meant to represent the actual measured TER of a given element, but it instead serves as a relative index indicating a potential stoichiometric mismatch. Various elements may be differentially acquired, assimilated, reused, and excreted, and the TSR index compares the elemental composition of the body of an animal and the food it consumed (not the food assimilated). The absorbed matter has a different elemental composition than the ingested matter, whose nondigestible surplus must be voided, and the physiological effort this requires is proportional to the difference between the food eaten and the food assimilated, which is proportional to the stoichiometric mismatch represented by the TSR index. Because the TSR index assumes that non-carbon elements are assimilated from food at a maximum rate (100\%), the actual mismatches in natural situations cannot be less than the estimated TSR values. Therefore, the TSR index serves as a conservative but convenient tool that facilitates the detection of elements that co-limit development and can be used to compare the severity of the limitations imposed by various foods on different consumers.

In the present study, the TSR index was used to investigate (1) the constraints imposed on the growth and development of saproxylophages because of the nutritional scarcity of dead wood and (2) a possible strategy for mitigating the constraints resulting from nutrient dynamics in decomposing dead wood. To this end, I calculated the TSR for various saproxylophagous and detritivorous insects that may use dead wood as a food source. The calculation was based on data on the elemental composition of arthropods compiled by Filipiak (2016; data collected worldwide based on reported mean concentrations of elements for approximately ten species of every taxon used, although the number of reported concentrations varied by element 
and taxon due to the scarcity of the reported data; see Supplemental Table 3 in Filipiak (2016) for details). The TSR was calculated based on the elemental composition of the bodies of adult saproxylophages $\left(C: X_{\text {consumer }}\right)$ and the elemental composition of the food eaten during their larval growth and development $(C$ : $\left.X_{\text {food }}\right)$. I used the mean values for element concentrations reported by Filipiak (2016) to calculate $C: X_{\text {consumer }}$ considering three taxa: beetles (Coleoptera), ants (Hymenoptera; Formicidae), and dipterans (Diptera). Exact values are presented in Filipiak (2016, see supplemental Table 3). To calculate the $C: X$ ratios for exemplary food sources of these insects, which constitute the numerator in the TSR index, I applied data on variously decomposed dead wood of different species of angiosperms and gymnosperms based on data collected worldwide (Grier 1978; Lambert et al. 1980; Foster and Lang 1982; Harmon et al. 1986; Preston et al. 1998, 2009; Palviainen et al. 2010a, b; Filipiak and Weiner 2014; Johnson et al. 2014; Köster et al. 2015; Palviainen and Finér 2015; Pearson et al. 2017). Considering all the above studies, the wood was aged 0-64 years after tree death. Based on every study, I utilized data on the elemental composition of the least decayed dead wood (or the youngest if the decay stage was not given) and the most decayed dead wood (or the oldest if the decay stage was not given) for every species investigated in a study. The least decayed wood was aged 0-2 years after tree death depending on the study, and the most decayed wood was aged 6-64 years after tree death. The least decayed wood in a single study is hereafter called undecayed, and the most decayed wood is termed highly decayed. I calculated TSRs for undecayed and highly decayed wood to investigate whether and to what degree the stoichiometric mismatch experienced by saproxylophages might be mitigated by feeding on nutritionally enriched decomposed wood compared to undecayed wood. In other words, I asked the question: "Can the dead wood of various tree species be sufficiently enriched during decomposition to allow saproxylophages to nutritionally balance their diets and thus overcome the limitation to growth and development posed by the nutritional scarcity of pure, undecayed wood?" Some of the analyzed studies did not contain data on C concentrations in the dead wood under study, for which $\mathrm{C}$ concentrations were assumed to be $50 \%$ dry mass based on Johnson et al. (2014), who did not find statistically significant differences from $C=50 \%$ in various species and ages $(0-16$ years of decay) of dead wood. Concerning concentrations of $\mathrm{C}$ reported in all the considered studies, for all the wood species, age, and the stage of decomposition, the mean value was $49 \%$ and minimal, $45 \%$ and maximal, $57 \%$.

The scarcity of seven elements (N, P, K, Mg, Fe, Zn, and Cu; Fig. 13.2) in dead wood may limit the growth and development of saproxylophagous insects regardless of the stage of wood decay and the insect taxa (exceptions: $\mathrm{Zn}$ tended to be not limiting for dipterans feeding on decayed wood, and $\mathrm{Mg}$ tended to be not limiting in decayed wood of Tsuga heterophylla (Raf.) Sarg.). This limitation occurred even though the TSRs calculated for N, P, Fe, and $\mathrm{Cu}$ for feeding on decayed wood tended to be 10-100 times lower than those for feeding on undecayed wood (exception: Fe for feeding on Tsuga heterophylla; Fig. 13.2). Also for $\mathrm{Zn}$ and $\mathrm{Mg}$, the calculations showed a tendency to mitigate stoichiometric mismatch during wood decomposition but to a lesser degree (Fig. 13.2). Magnesium limitation tended to be lower in 


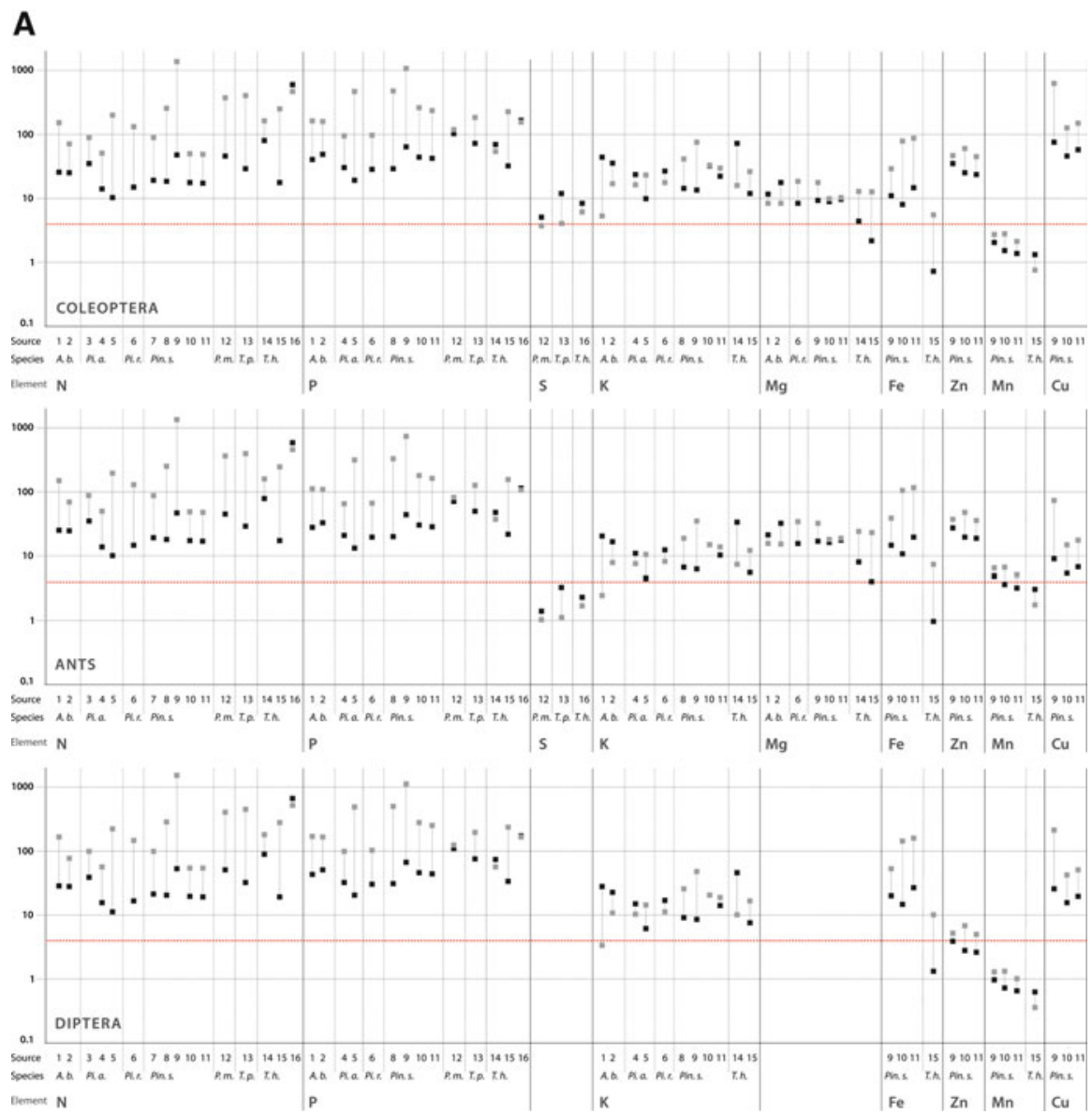

Fig. 13.2 Stoichiometric mismatches (trophic stoichiometric ratios, TSRs) calculated for detritivorous/saproxylophagous insects feeding on various species of dead wood: (A) gymnosperms and (B) angiosperms. TSR values were calculated based on data from the literature (means) on the elemental composition of dead wood and the elemental composition of the adult bodies of insects. Undecayed wood (gray squares) — the least decayed/youngest dead wood investigated in a single study; highly decayed wood (black squares) - the most decayed/oldest dead wood investigated in a single study. Corresponding squares connected by a line, dead wood investigated in a single (the same) study. Species symbols of gymnosperms, A. b., Abies balsamea; Pi. a., Picea abies; Pi. r., Picea rubens; Pin. s., Pinus sylvestris; P. m., Pseudotsuga menziesii; T. p., Thuja plicata; T. h., Tsuga heterophylla; and angiosperms, Ac. s., Acer saccharum; Al. g., Alnus glutinosa; Al. i., Alnus incana; B. a., Betula alleghaniensis; B. pe., Betula pendula; B. pe and B. pu., Betula pendula and Betula pubescens; F. g., Fagus grandifolia; and P. t., Populus tremula. Source literature for the elemental composition of dead wood: Foster and Lang (1982), 1 and 6; Lambert et al. (1980), 2; Köster et al. (2015), 3, 7, 18, 19, 22, and 24; Palviainen and Finér (2015), 4; Filipiak and Weiner (2014), 9; Pearson et al. (2017), 10 and 11; Preston et al. (1998), 12, 13, and 16; Grier (1978), 14; Preston et al. (2009), 15; Johnson et al. (2014), 17, 20, and 23; and Palviainen et al. (2010a, b), 5, 8, and 21. Data source for insect elemental compositions: literature review by Filipiak (2016). The red, dashed line shows $T S R=4$, and values below this threshold indicate the limiting effect on the growth and development of an insect by the scarcity of a given element in the food consumed during its larval period. The scarcity of $\mathrm{N}, \mathrm{P}, \mathrm{K}, \mathrm{Mg}, \mathrm{Fe}, \mathrm{Zn}$, and $\mathrm{Cu}$ in the dead wood of different species may limit the growth and development of various saproxylophage taxa, and the power of this 
B
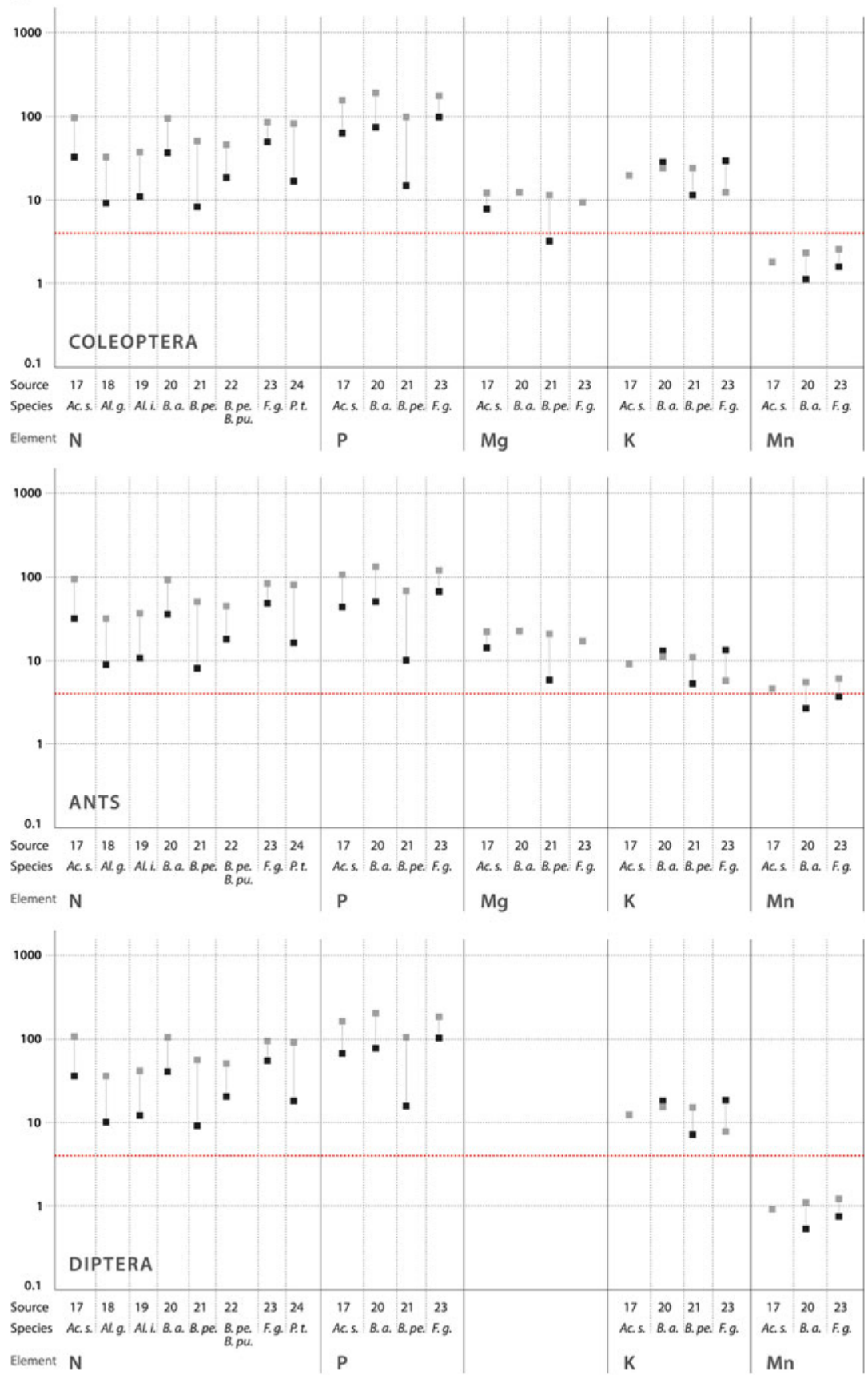

Fig. 13.2 (continued) limitation depends on the species and decay stage of the wood and the insect taxa. In most cases, the nutrient dynamics in decomposing dead wood are not sufficient to overcome the limiting effects, which persist even if mitigated by the nutritional enrichment of decomposing wood. Therefore, diet supplementation with non-woody compounds is required 
decayed than undecayed wood for all the investigated species except Abies balsamea (L.) Mill. (Fig. 13.2). Sulfur may be limiting for beetles but not for ants, and Mn may be a limiting element for ants but not for beetles and dipterans (Fig. 13.2). The effect of the limitations posed by $\mathrm{K}$ and $\mathrm{Mg}$ scarcity tended to differ with the wood species. Furthermore, K limitation tended to be lower in decayed than in undecayed wood in Pinus sylvestris L. and Fagus grandifolia Ehrh., but for the other investigated species, K limitation tended to be higher in decayed wood or depended on the study (Fig. 13.2). The analysis of the limitations posed on the growth and development of insects by the multielemental stoichiometry of dead wood (Fig. 13.2) is simple and rough yet instructive; it shows the complexity of the relationship between the nutritional value of dead wood and its potential consumers. Several factors should be taken into consideration when discussing this issue: (1) the general nutritional value of dead wood; (2) changes in the nutritional value of the wood that occur during decomposition; (3) differences between the behavior of atoms of various elements, particularly increasing/decreasing concentrations of different elements with wood decay; (4) differences between various species of wood (e.g., Tsuga heterophylla versus other investigated gymnosperms or angiosperms versus gymnosperms; Fig. 13.2). This analysis also shows the scarcity of the knowledge of the nutritional value of dead wood for saproxylophages and the bias toward gymnosperms (especially Pinus sylvestris). In the following sections of this chapter, I will summarize the existing knowledge on the nutrient dynamics in decomposing dead wood, and I will relate the data on the dynamic changes in wood stoichiometry with the nutritional needs of saproxylophages. The analysis (Fig. 13.2) revealed that the nutritional scarcity of dead wood limits the growth and development of saproxylophages because of imbalanced multielemental stoichiometry. In the following subsections, I will discuss the mechanism by which saproxylophages mitigate this limitation by utilizing a fungal network that connects nutritionally scarce dead wood with nutritionally rich patches of the outside environment.

\subsection{Nutrient Dynamics in Decomposing Dead Wood: Short-Term (Several Years) vs. Long-Term (Dozens of Years) Changes}

Pure wood is rich in polysaccharides but includes few of the other biomolecules required for saproxylophage growth and development (Parkin 1940; Pettersen 1984). The actions of insects and mites include bringing symbiotic fungi or soil into the wood environment, which may contribute to the nutritional enrichment of the internal dead wood environment (Ulyshen and Wagner 2013; Ulyshen 2016) but not to the wood itself. Similarly, the dead wood environment may be nutritionally enriched by the accumulation of loose organic material in tree hollows (Landvik 
et al. 2016) or by the accumulation of the feces of saproxylophages (Chen and Forschler 2016; Sánchez et al. 2017). Another source of nutritional enrichment may be the action of ants bringing nutrients in the form of harvested organisms and excreta from the outside environment (Pinkalski et al. 2015). Finally, fungi inhabiting dead wood may create mycelial networks that extend beyond the wood itself, allowing them to import nutrients from external sources, thus improving substrate quality for invertebrates (Filipiak et al. 2016; Filipiak and Weiner 2017a). However, the wood tissues themselves cannot be nutritionally enriched in this way, so it was assumed that the wood mainly becomes enriched via the digestion of polysaccharides and the loss of $\mathrm{C}$ through respiration as $\mathrm{CO}_{2}$ by microorganisms during decomposition (Swift et al. 1979; Boddy and Watkinson 1995). This process should result in an increase in the percentages of non-sugar nutrients and non-C elements in wood (Swift et al. 1979; Boddy and Watkinson 1995), and the nutritional quality of wood can be represented as the ratios of the concentrations of $\mathrm{C}$ to other elements (i.e., $C: X$ ratio, where $C$ represents the concentration of carbon and $X$ represents the concentration of any non-carbon element x) (Swift et al. 1979; Boddy and Watkinson 1995; cf. Elser et al. 2000a; Sterner and Elser 2002, where the atomic ratio is utilized instead of the mass ratio). Changes in this ratio during decomposition have been used to discuss nutrient dynamics in decomposing dead wood (Swift et al. 1979; Boddy and Watkinson 1995; Filipiak et al. 2016), and it has been noted that nutrient importation via fungal mycelium probably occurs in the early stages of wood decomposition (first few years of decomposition) and results in an increase in the absolute contents of certain non-C elements (Stark 1972; Swift 1977; Swift and Boddy 1984; Wells et al. 1990; Clinton et al. 2009). However, this phenomenon has received limited research attention, with studies primarily focused on the nutrient losses that occur during later stages of decomposition (5-several dozen years of decomposition; Foster and Lang 1982; Harmon et al. 1986; Dighton 2003, 2007; Palviainen et al. 2010a, b; Köster et al. 2015). Therefore, it was assumed that $\mathrm{C}$ loss is the main driver of the observed increase in the nutritional quality of dead wood, so the eventual transport of substances by fungi from external sources may be neglected (Swift et al. 1979; Harmon et al. 1986; Wells and Boddy 1995; Johnson et al. 2014; Köster et al. 2015; Clymans et al. 2016). In this chapter, the nutrient dynamics observed in decomposing wood will be discussed in the context of the nutritional needs of saproxylophages, so in contrast to most previous studies, the short-term (several years) changes in the nutrient concentrations in the dead wood environment will be discussed with a focus on elements that are physiologically important for saproxylophagous insects. Additionally, the mechanisms responsible for these changes will be further discussed in relation to the growth, development, and fitness of saproxylophages.

Studies of dead wood decomposition processes have reported various and sometimes opposing changes in the concentration of elements, and such conflicting results can be attributed to the different methods used to classify the stages of wood decay. Certain methods are based on measuring samples collected from dead boles or stumps that may not represent the stage of decay of the entire bole/stump, and differences may be related to variation in samples of dead wood collected from 
different tree species or from wood with bark, wood alone (sapwood and heartwood), sapwood alone, or heartwood alone. An additional source of variation may be the location of the decomposing wood, which would be related to differences in environmental conditions and decomposer communities (e.g., Rinne et al. 2017 showed the temperature dependency of $\mathrm{N}$ fixation). It is also possible that the dead wood of various species has specific nutrient dynamics (Fig. 13.2).

Lambert et al. (1980) studied mass loss and chemical changes in decaying boles of balsam fir (Abies balsamea; subalpine balsam fir forest, North America) and measured the concentrations of $\mathrm{C}, \mathrm{N}, \mathrm{P}, \mathrm{Ca}, \mathrm{Mg}, \mathrm{K}$, and $\mathrm{Na}$, and these authors did not observe significant differences in the element concentrations among (1) standing dead trees, (2) fallen and slightly decomposed logs, and (3) fallen and moderately decomposed logs. Dead wood in advanced states of decay presented significantly increased concentrations of $\mathrm{N}, \mathrm{P}$, and $\mathrm{Mg}$ relative to less decayed wood, but the concentrations of other elements were not found to change significantly. Lambert et al. (1980) also studied changes in the absolute amounts of elements in boles aged 0-70 years over seven decades. Bole death spurred a continuous increase in the absolute levels of $\mathrm{N}$, whereas the absolute $\mathrm{P}$ levels tended to increase over the first 10 years and then decrease. In contrast, the absolute levels of $\mathrm{Ca}, \mathrm{Mg}$, and $\mathrm{K}$ tended to decrease (Lambert et al. 1980). However, different results were reported by Grier (1978) in western hemlock-sitka spruce (Tsuga heterophylla) ecosystems (Central Oregon Coast, North America); in this case, fallen logs aged 2-38 years were studied, and the absolute levels of $\mathrm{N}, \mathrm{P} \mathrm{Ca}, \mathrm{Mg}$, and $\mathrm{K}$ tended to decrease between the 2 nd and 5th years of decomposition. The long-term changes in the concentrations and absolute levels of $\mathrm{N}, \mathrm{Ca}, \mathrm{Mg}$, and $\mathrm{Na}$ tended to increase while $\mathrm{P}$ and $\mathrm{K}$ tended to decrease during decomposition; the $\mathrm{C}$ content was not determined. In a northern hardwood forest in North America, Johnson et al. (2014) studied the nutrient dynamics of dead sugar maple (Acer saccharum Marsh.), American beech (Fagus grandifolia Ehrh.), and yellow birch (Betula alleghaniensis Britt.) wood over 16 years of decomposition and reported increases in $\mathrm{N}, \mathrm{P}$, and $\mathrm{Ca}$ concentrations in all studied species, decreases in $\mathrm{K}$ concentrations in two species, decreases in the $C: N$ ratios in all species, decreases in the $C: P$ ratios in two species, decreases in the $N: P$ ratio in one species, and an increase in the $N: P$ ratio in one species. The total amounts of $\mathrm{K}$ and $\mathrm{Mn}$ decreased in all species, and the total levels of $\mathrm{N}, \mathrm{P}, \mathrm{Ca}$, and $\mathrm{Mg}$ increased over the first 2-10 years depending on the species and decreased after 10 years in all species. In Asia, Yuan et al. (2017) studied the decomposition of Pinus armandii Franch. and Quercus aliena Blume wood over an 18-year period, and a decrease in $\mathrm{K}$ concentrations and an increase in $\mathrm{C}, \mathrm{N}, \mathrm{P} \mathrm{Ca}$, and $\mathrm{Mg}$ concentrations were observed for both species. The $C: N$ ratios tended to decrease over time, yet the pattern of change in elemental concentrations and $C: N$ ratios differed between species. Laiho and Prescott (2004) concluded in their review, which was based on a dataset that considered a decomposition period spanning 100 years for various wood species worldwide, that $\mathrm{N}$ and $\mathrm{P}$ concentrations typically increase during decay while the concentrations of other elements tend to vary. However, all these studies failed to consider the nutritional needs of saproxylophagous insects that develop in dead wood over several years (during 


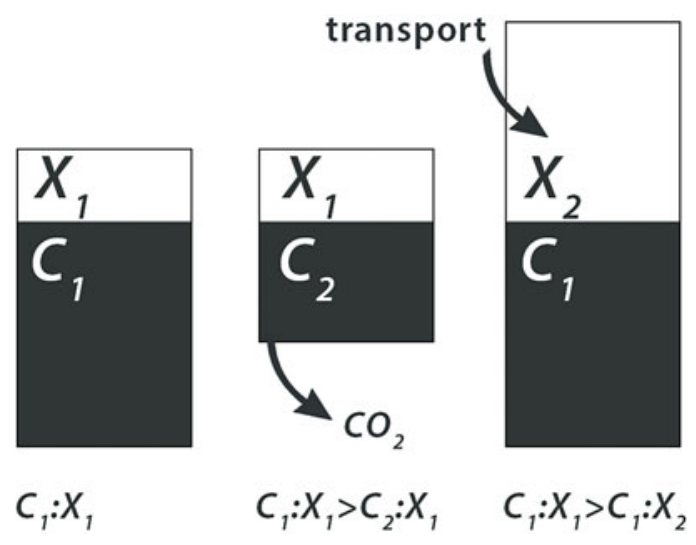

Fig. 13.3 Two mechanisms that contribute to the nutritional enrichment (an increase in elements other than C) of dead wood during decay: (1) C loss and (2) the transport of outside nutrients. A decrease in the $C: X$ ratio during the initial stages of dead wood decomposition should favor the growth and development of saproxylophages. $X$ represents the concentration of any non-carbon element $x$ and $C$ represents the concentration of carbon

which specific changes in nutrient concentrations may occur) that are not related to long-term changes. Therefore, the mechanisms contributing to the changes in the nutritional quality of decaying wood that occur during the time corresponding to saproxylophage growth and development cannot be interpreted reliably. Concentrations of non-carbon elements $(X)$ can increase as decay proceeds because either the absolute amounts of $\mathrm{C}$ decrease or the absolute amounts of element $\mathrm{x}$ increase (Fig. 13.3), and lower $C: X$ ratios indicate better nutritional conditions for saproxylophages (Filipiak and Weiner 2014; Filipiak et al. 2016; Filipiak and Weiner 2017a; Fig. 13.3). Assuming $\mathrm{CO}_{2}$ loss from dead wood during decomposition is the main factor that contributes to wood nutritional enrichment, a similar increase in the concentrations of all non-carbon elements should be observed. Table 13.1 shows the estimated decrease in $C: X$ ratios in decomposing wood calculated from the decrease in the density of decaying wood in which there is no net import of nutrients; the estimations were adapted from Boddy and Watkinson (1995). For comparison, Table 13.1 also shows the measured concentrations of non-carbon elements in decomposing wood. The measured concentrations changed to differing degrees during the first 4 years of decomposition, leading to different decreases in $C: X$ ratios during decomposition depending on the non-carbon element (Table 13.1). This change suggests that at least in the initial stages of decomposition, mechanisms other than $\mathrm{C}$ loss via respiration may highly contribute to the observed nutrient dynamics and the rearrangement of $C$ :other element ratios. During the very early stages of decay, the nutritional composition of dead wood may be dramatically rearranged (Filipiak et al. 2016), so the processes that occur during the early stages of decomposition that nutritionally enrich wood and allow saproxylophages to grow, develop, and reach maturity should be clarified. The few studies conducted on the nutritional changes in dead wood during early stages of decomposition (0-5 years) 
Table 13.1 Decrease in the $C: X$ ratios $(C$, concentration of carbon; $X$, concentration of any non-carbon element $x$ ) in decomposing wood

\begin{tabular}{|c|c|c|c|c|c|c|c|c|c|c|}
\hline \multirow[t]{3}{*}{ Mass loss (\%) } & \multicolumn{10}{|c|}{ Decrease in estimated $\boldsymbol{C}: \boldsymbol{X}$ ratios (Boddy and Watkinson 1995) } \\
\hline & $C: N$ & $C: P$ & C:K & $\begin{array}{l}C: \\
C a\end{array}$ & $\begin{array}{l}: \\
M g\end{array}$ & & & & & \\
\hline & \multicolumn{5}{|c|}{$\begin{array}{l}n \text {-fold decrease from the original } \\
\text { mass }\end{array}$} & & & & & \\
\hline 29 & 1.41 & 1.41 & 1.41 & 1.41 & 1.39 & & & & & \\
\hline 46 & 1.86 & 1.85 & 1.85 & 1.85 & 1.85 & & & & & \\
\hline 64 & 2.78 & 2.78 & 2.79 & 2.76 & 2.78 & & & & & \\
\hline 82 & 5.61 & 5.56 & 5.53 & 5.63 & 5.55 & & & & & \\
\hline \multirow[t]{3}{*}{ Decay stage } & \multicolumn{10}{|c|}{ Decrease in measured mean $\boldsymbol{C}: \boldsymbol{X}$ ratios (Filipiak and Weiner 2014) } \\
\hline & $C: N$ & $C: P$ & C:K & $\begin{array}{l}C: \\
C a\end{array}$ & $\begin{array}{l}: \\
M g\end{array}$ & $\begin{array}{l}\mathrm{C}: \\
\mathrm{Na}\end{array}$ & $\begin{array}{l}\mathrm{C}: \\
\mathrm{Fe}\end{array}$ & $\begin{array}{l}\text { C: } \\
Z n\end{array}$ & $\begin{array}{l}: \\
M n\end{array}$ & $\begin{array}{l}C: \\
C u\end{array}$ \\
\hline & \multicolumn{10}{|c|}{$n$-fold decrease from the undecayed dead wood } \\
\hline $\begin{array}{l}\text { Moderately } \\
\text { decayed }\end{array}$ & 4.45 & 5.41 & 2.01 & 1.13 & 1.14 & 1.02 & 2.27 & 1.18 & 0.92 & 8.12 \\
\hline Highly decayed & 27.12 & 16.87 & 5.60 & 1.48 & 1.90 & 1.53 & 2.65 & 1.35 & 1.33 & 8.15 \\
\hline \multicolumn{11}{|c|}{$\begin{array}{l}\text { Theoretical and measured values are compared based on theoretical data estimated under the } \\
\text { assumption that the loss of wood mass is only caused by the release of } \mathrm{CO}_{2} \text { during respiration } \\
\text { and that a net loss or importation of minerals does not occur during the decay process (Boddy and } \\
\text { Watkinson 1995), and the measured values are the means for pine stumps aged } 0-4 \text { years after tree cutting } \\
\text { (Filipiak and Weiner 2014). The theoretical values show similar } C: X \text { ratios declines for all elements } x \\
\text { considered, and the measured values show differing decreases in } C: X \text { ratios for various elements x. }\end{array}$} \\
\hline
\end{tabular}

suggest that nutrient transport by fungi from external sources plays a crucial role in the nutritional rearrangement of wood during the time of saproxylophage developmental requirements (Filipiak and Weiner 2014; Filipiak et al. 2016; Filipiak and Weiner 2017a; temperate deciduous forest, Europe). The further changes in dead wood nutrient dynamics may depend on the changes during the first few years of decomposition, when dead wood may be considerably enriched in several nutrients. For pine stumps in Central Europe, concentrations of $\mathrm{N}, \mathrm{P}, \mathrm{K}, \mathrm{Na}, \mathrm{Mg}, \mathrm{Fe}$, and $\mathrm{Cu}$ may increase by approximately 2 to 25 times, depending on the element, during the first 4-5 years of wood decay (Filipiak and Weiner 2014; Filipiak et al. 2016). The increase is considerable and reflects the increase in the absolute amounts of these elements in the wood (Filipiak et al. 2016), and such a nutritionally supplemented wood may be further exploited during later stages of decay by various taxa of saproxylophages. A 16-year study of the nutrient dynamics in the wood and bark of three tree species indicated that the net amount of $\mathrm{N}, \mathrm{P}, \mathrm{Mg}$, and $\mathrm{Ca}$ increased in a species-dependent manner during the first 2 years of decomposition. However, detailed analyses of the observed patterns are impossible because of the small sample size and variability in element concentrations (Johnson et al. 2014). One could ask whether the age of decomposing wood is a good proxy for its nutritional characteristics. If changes in the nutrient concentrations of dead wood can result from microbial action with fungi being responsible for enrichment via the transport of outside nutrients, then fungal infection of dead wood may better explain the 

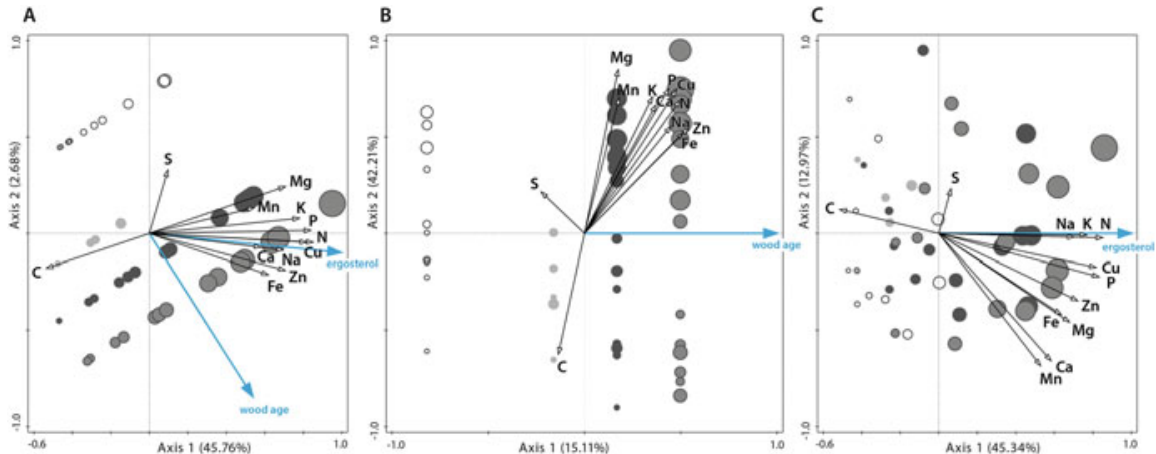

Dead wood age (pine stumps years after tree cutting):

O: less than 1 year

Fig. 13.4 Multivariate analysis of the stoichiometric relationships between the ergosterol content, dead wood age, and 12 studied elements. The RDA plot and the first two axes are shown. (A) Plot considering ergosterol content and wood age; (B) plot considering wood age alone; and (C) plot considering ergosterol content alone. Circles denote single pine stumps in various stages of decomposition, and the size of the circles denotes the ergosterol content of the stumps, $n=45$. For all axes in $\mathbf{A}, \mathbf{B}$, and $\mathbf{C}, p<0.05$

observed variation in nutrient concentrations than the age of the wood. For this reason, I compared the relationship between (1) dead wood age and the concentration of nutritional elements and, for the same wood samples, between (2) levels of fungal hyphae and the concentrations of nutritional elements to examine whether the variation in the elemental concentrations of dead wood with age was attributable to fungal nutrient transport (Fig. 13.4). I examined the data from 45 pine stumps of known age in various stages of decay (a few months to 5 years after tree cutting) that included the concentrations of 12 elements (C, N, P, S, K, Na, Ca, Mg, Fe, Zn, Mn, and $\mathrm{Cu}$ ) and a known concentration of ergosterol, which is a proxy for the levels of fungal hyphae, from Filipiak et al. (2016). A redundancy analysis (RDA) was performed to simultaneously compare the composition of multiple elements in wood and the relationship between ergosterol levels and wood age (Fig. 13.4). An analysis of the ergosterol content and wood age (Fig. 13.4A) suggested that concentrations of elements in wood (except $S$ ) are closely correlated with ergosterol levels (amount of fungi) and may be slightly correlated with wood age. The first two axes explained $48.44 \%$ of the total variance. Relationships between ergosterol content and the concentration of elements are denoted by vectors that symbolize the contents of ergosterol and the elements around the first axis, which explained $45.76 \%$ of the total variance (C concentration declined, and the concentrations of other elements, except $\mathrm{S}$, increased as did that of ergosterol). A vector symbolizing wood age positioned between axes 1 and 2 was situated closer to the 2 nd axis that explained only $2.68 \%$ of the total variance. High variation was observed in ergosterol content, and it was not related to wood age. Element concentration was strongly correlated with ergosterol content, and because fungi translocate nutrients to the wood, the amount of fungal tissue may be assumed to be responsible for the variation in the 
element concentrations in the wood. Thus, the variation in element concentrations was not dependent on the age of the dead wood, but it was dependent on the amount of fungi inhabiting the wood. Indeed, an analysis that focused strictly on wood age revealed a weak correlation between wood element concentrations and wood age (Fig. 13.4B). Axis one in Fig. 13.4B is related to wood age and explained only $15.11 \%$ of the total variance. The element concentrations were positioned closer to the 2nd axis and explained $42.21 \%$ of the total variance (Fig. 13.4B). The concentrations of $\mathrm{Fe}, \mathrm{Zn}, \mathrm{Na}$, and $\mathrm{N}$ were correlated with wood age to the highest degree, but they were not strong for any of these elements. The analysis of ergosterol content alone revealed a random distribution of stumps by age in the RDA plot (Fig. 13.4C), and axis 1 , which is related to ergosterol content and the element concentrations (except S), explained $45.34 \%$ of the total variance. Carbon concentrations decreased, while the concentrations of other elements (except S) increased along with ergosterol content. The elements most closely correlated with ergosterol were $\mathrm{N}, \mathrm{K}, \mathrm{Na}, \mathrm{Cu}$, and $\mathrm{P}$, and these correlations were strong. Of these elements, the transport of $\mathrm{N}, \mathrm{K}$, $\mathrm{Cu}$, and $\mathrm{P}$ to dead wood by fungi was reported in a previous study (Filipiak et al. 2016).

Thus, the age of dead wood is not a good proxy for its nutritional characteristics, while measures of fungal hyphae inside the dead wood environment are related to the observed pattern of $C: X$ decline during decomposition. Previous studies have shown that fungal transport increases the total amount of $\mathrm{N}, \mathrm{P}, \mathrm{K}, \mathrm{Cu}$, and $\mathrm{Fe}$, and potentially $\mathrm{Na}$ and $\mathrm{Mg}$, in wood infested by fungi, and this may be the main factor explaining decreases in $C: X$ during the initial stages of decomposition (first several years; Filipiak et al. 2016). Therefore, the age of dead wood may not be related to its nutritional quality, and the amount of fungal hyphae within dead wood may be a better proxy for nutritional quality and thus usability by saproxylophages.

\subsection{Nutrient Dynamics Related to the Requirements of Saproxylophages: A Case Study Utilizing Existing Data on the Ecological Stoichiometry of Saproxylophagous Insects}

To date, some data have been published on the nutrient dynamics of decaying wood associated with the nutritional needs of saproxylophages that use three species of beetles as model organisms: Stictoleptura rubra, Arhopalus rusticus (Coleoptera, Cerambycidae), and Chalcophora mariana (Coleoptera, Buprestidae) (Filipiak and Weiner 2014, 2017a; Filipiak et al. 2016). The goal of this chapter is to discuss the nutrient dynamics in dead wood in the context of the requirements of wood eaters, so in this subsection, I will focus on the three model species of beetles for which relevant data exists. All three beetles inhabit the same environment (dead pine wood) and exploit the same resources, but they belong to two families (Cerambycidae and Buprestidae) and have different life histories, resulting in different adult body sizes 
(Filipiak and Weiner 2014). Therefore, the beetles differ in their nutritional needs and must collect different amounts of nutrients during larval growth to compose the adult body. In the literature (Dominik and Starzyk 2004), the development times for these species are reported to be 3 years in the smallest beetle, $S$. rubra; 2-4 years in A. rusticus, which is of intermediate size; and 5-6 years in the largest of these beetles, $C$. mariana. Their mean body sizes are as follows (species, female and male in grams dry mass): S. rubra, 0.07 and 0.03 ; A. rusticus, 0.13 and 0.08 ; and C. mariana, 0.22 and 0.18 (Filipiak and Weiner 2014). I shall start by relating the available data on the body composition of various groups of insects (Coleoptera, Diptera, and ants) to the nutritional composition of dead wood in different stages of decay and that of fungi to investigate the possible nutritional mismatches experienced by various groups of saproxylophagous insects, the limitations to their growth and development posed by these mismatches, and the possibilities for mitigating these mismatches.

I used the TSR index (described in Sect. 13.6) to investigate (1) the constraints imposed on the growth and development of saproxylophages as a result of the nutritional scarcity of dead wood and (2) methods of mitigating the constraints resulting from these nutrient dynamics. Thus, I calculated the TSRs for various saproxylophagous and detritivorous insects that may feed on dead wood and performed two analyses. Analysis 1, illustrated in Fig. 13.5, was performed to answer the question: "How do fungi contribute to mitigating the stoichiometric mismatch and nutritional limitation experienced by various insects feeding on dead wood?" In this analysis, I utilized data available from the literature on the elemental composition of various insects, fungi, and dead wood collected worldwide. Analysis 2, which is illustrated in Fig. 13.6, was performed to investigate how dead wood nutrient dynamics are related to the nutritional requirements of saproxylophages inhabiting the wood. In this analysis, I focused on the example of trophic relationship between saproxylophages, dead wood, and fungi, utilizing the data on the three species of wood-boring beetles (Stictoleptura rubra, Arhopalus rusticus, and Chalcophora mariana) inhabiting pine stumps. The data used for both analyses contained precise average, variability and minimal and maximal values for $\mathrm{C}$ and other elements, which allowed for the potential mean and minimal and maximal values of the TSR index to be calculated.

The analysis of the literature related to the nutrient dynamics in dead wood and the elemental compositions of saproxylophagous insects revealed a lack of data associated with the nutritional needs of the organisms that inhabit wood, and the estimates are incomplete due to an absence of data on several physiologically important elements (atoms of 25 elements should be considered; Cherif 2012; Kaspari and Powers 2016) as well as the different saproxylophage taxa and various species of dead wood. Nevertheless, the extrapolation of such calculations to generalize the interactions between dead wood and wood eaters is highly instructive and may lead to important and testable hypotheses. 


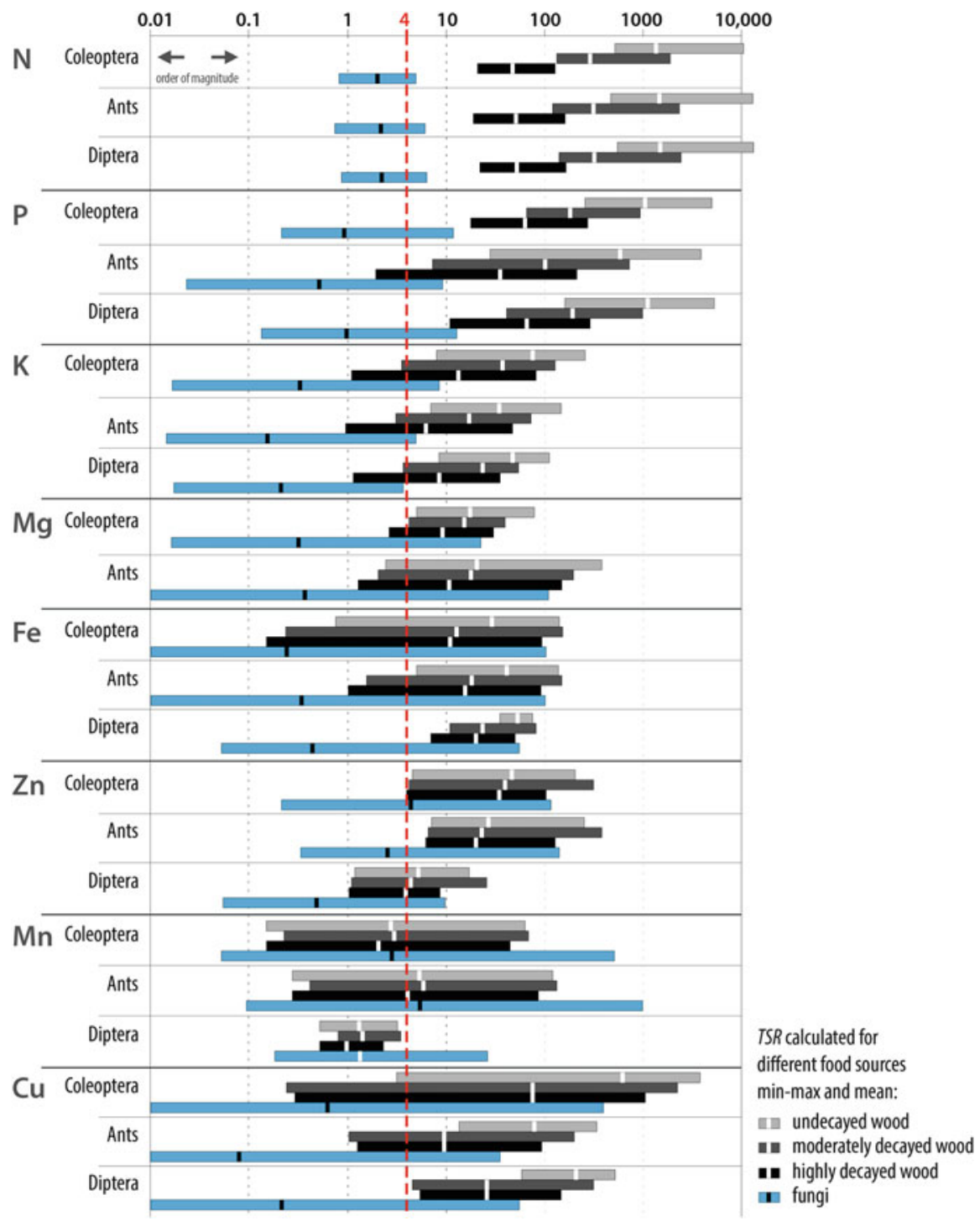

Fig. 13.5 Stoichiometric mismatches (TSRs) calculated for detritivorous/saproxylophagous insects that may use dead wood and fungi as food. TSR values were calculated for four sources of food: variously decomposed wood divided into three decay classes (source: Filipiak and Weiner 2014) and fungi (source: Filipiak 2016). Bars denote the minima and maxima, and white and black dashes denote means. The Y-axis scale is logarithmic. Source of insect elemental composition data: Filipiak 2016. TSR values $\geq 4$ denote limitations on growth, and the dotted red line denotes the threshold value $(T S R=4)$. The growth and development of insects feeding on dead wood may be co-limited by $\mathrm{N}, \mathrm{P}, \mathrm{Cu}, \mathrm{K}, \mathrm{Mg}, \mathrm{Zn}$, and Fe scarcity, and the strength of this limitation is mitigated as wood is decomposed by one or two orders of magnitude during the first 4 years of decomposition. This limitation may be completely mitigated using fungi as a food source 


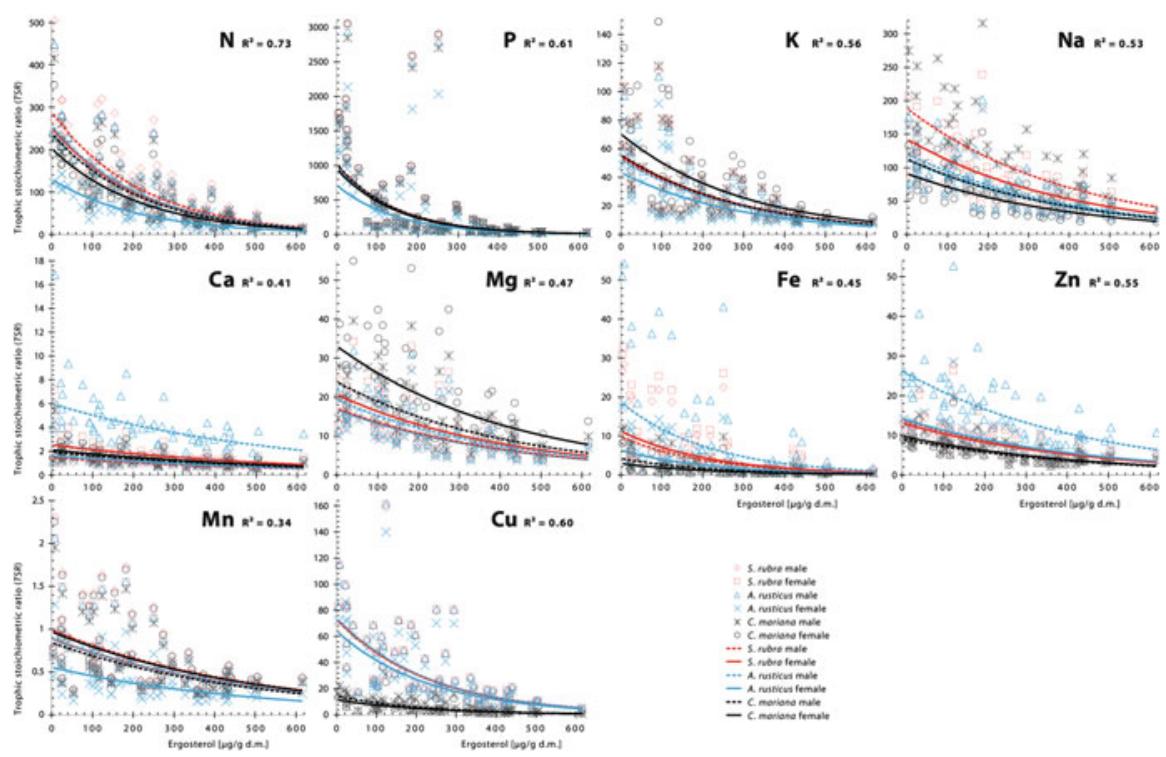

Fig. 13.6 Relationships between ergosterol content (proxy for fungi) in dead wood and the nutritional limitations imposed on the growth and development of saproxylophagous beetles inhabiting the wood expressed as TSRs. TSR values $\geq 4$ denote the limitations caused by a scarcity of atoms of the considered element, and these limitations are more severe for TSR values substantially different than 4. Calculations were based on the mean element concentrations in beetle bodies (source: Filipiak and Weiner 2014) and the element concentrations and ergosterol content of dead wood inhabited by the studied beetles (aged a few months to 5 years) (source: Filipiak et al. 2016)

\subsubsection{Analysis 1}

I calculated the TSR index based on data on the elemental compositions of insects compiled by Filipiak (2016; data collected worldwide based on reported mean concentrations of elements for approximately ten species of every taxon used, but the number of reported concentrations varied by element due to scarcity of data on the elemental composition of the insects). The TSR was calculated based on the elemental compositions of adult bodies $\left(C: X_{\text {consumer }}\right)$ and the food eaten during the growth and development of these bodies $\left(C: X_{\text {food }}\right)$. To calculate the $C: X$ ratios for exemplary food sources for these insects, which constitute the numerator in the TSR index, I applied data on (1) variously decomposed dead wood aged 1-4 years and divided into three decay classes that differed in the amounts of fungal hyphae growing inside the wood (Filipiak and Weiner 2014; pine stumps collected from the Puszcza Niepołomicka Forest, Lesser Poland; $N=8-26$ depending on the decay class and the element) and on (2) the elemental compositions of fungi that may grow inside dead wood and be used by saproxylophages as food instead of wood (Filipiak 
2016; data collected worldwide based on reported mean concentrations of elements for a species, utilizing from 4 (C) to 69 (Fe, $\mathrm{Zn}, \mathrm{Mn}$ ) mean values).

The analysis revealed (Fig. 13.5) that limitations of seven elements $(\mathrm{N}, \mathrm{P}, \mathrm{Cu}, \mathrm{K}$, $\mathrm{Mg}, \mathrm{Zn}$, and $\mathrm{Fe}$ ) had the greatest effect on insect development ( $\mathrm{Zn}$ may not be limiting for Diptera), with calculated TSR values above the threshold of 4 (Fig. 13.5). For P and N, the TSRs calculated for feeding on moderately decayed wood were approximately ten times lower than those for feeding on undecayed wood, and the $T S R$ s calculated for feeding on heavily decayed wood were approximately 100 times lower than those for feeding on undecayed wood. For $\mathrm{Cu}$, the TSRs calculated for feeding on both (1) moderately decayed wood and (2) heavily decayed wood were approximately ten times lower than those for feeding on undecayed wood. For K, the $T S R$ s decreased almost tenfold from undecayed to heavily decayed wood, and for $\mathrm{Mg}$ and Fe, the TSRs declined approximately two- to threefold from undecayed to heavily decayed wood. All the elements were considered limiting to insect growth and development, even for the most nutritious wood sample (heavily decayed wood). These limitations, however, are mitigated when insects feed on fungal hyphae that overgrow wood during decay. Therefore, the nutrient dynamics found in decomposing wood may mitigate the nutritional limitations on the growth and development of saproxylophagous insects, but these dynamics provide insufficient nutrients. Thus, selective feeding on fungal hyphae might supply saproxylophages with their required nutrients. Therefore, wood ingested by saproxylophages as they form corridors in dead wood may not be a major source of body-building nutrients for these organisms, and growing insects likely rely on fungi as a source of nutrition.

\subsubsection{Analysis 2}

During the first few years of dead wood decomposition, the transport of nutrients from the external environment through fungal hyphae shapes nutrient dynamics and transforms nutritionally scarce wood environments into niches that are nutritionally adequate for saproxylophagous insects (Filipiak et al. 2016; Filipiak and Weiner 2017a). It has been suggested that the transport of nutrients from the environment may continue during latter stages of wood decomposition, but the leaching of nutrients from wood into the environment may also occur. However, the $C: X$ ratios continue to decrease, potentially because of C loss (Boddy and Watkinson 1995; Laiho and Prescott 2004; Johnson et al. 2014), so long-term C losses from decomposing wood initially enriched by fungi with non-C elements may further mitigate the nutritional limitations experienced by insects inhabiting dead wood during later stages of decay. Hence, the initial enrichment of the wood environment with nutrients transported by fungi from the outside may be an important mechanism that further shapes the long-term nutrient dynamics in dead wood. Therefore, I utilized the available data from the literature to investigate the degree to which the nutritional enrichment of dead wood during the first few years of decay might mitigate the nutritional constraints of saproxylophagous insects feeding on dead 
wood. For the three species of saproxylophagous beetles examined, I was able to determine the relationships between nutritional limitations and the amounts of fungi (expressed as the concentrations of ergosterol) within dead wood over the first 5 years of decay (Fig. 13.6). I used data published on variously decomposed dead wood aged from a few months to 5 years (Filipiak et al. 2016; 77 pine stumps collected in Puszcza Niepołomicka Forest). The TSR values for these stumps could be related to the ergosterol content (proxy for fungus levels) that was measured by Filipiak et al. (2016), and these stumps were inhabited by three species of saproxylophagous beetles that differed in their life history characteristics: Stictoleptura rubra (Cerambycidae), the smallest one with a larval development time reaching 3 years; Arhopalus rusticus (Cerambycidae), which is intermediate in size with a larval development time reaching 4 years; and Chalcophora mariana (Buprestidae), the largest beetle with a larval development time reaching 6 years (Filipiak and Weiner 2014, 2017a; Filipiak et al. 2016). Based on these data, I calculated TSRs for ten elements (N, P, K, Na, Ca, Mg, Fe, Zn, Mn, and Cu) and for the three species of the beetles (females and males separately) feeding on wood in various stages of decomposition and containing various amounts of fungi (expressed as ergosterol content) to show the nutrient dynamics in decomposing dead wood in the context of wood eater requirements. The calculated TSRs involved approximately 4 to $600 \mu \mathrm{g}$ of ergosterol per g of wood (dry mass), and they decreased with increasing ergosterol content (Fig. 13.6) by approximately 100 -fold for $\mathrm{P}$ (from 3000 to 30), 30-fold for $\mathrm{N}$ (from 450 to 15), 45-fold for Fe (from 30 to 0.7 ), 30-fold for $\mathrm{Cu}$ (from 160 to 5 for cerambycids and from 30 to 1 for buprestids), 13-fold for $\mathrm{K}$ (from 110 to 8.5), and 10-fold for $\mathrm{Na}, \mathrm{Mg}, \mathrm{Zn}$, and $\mathrm{Ca}$ (Na, from 200 to 24; $\mathrm{Mg}$, from 30 to $3 ; \mathrm{Zn}$, from 30 to 3 ; and $\mathrm{Ca}$, from 7 to 0.7 ). Although the TSR levels decreased by almost tenfold for $\mathrm{Mn}$, this element was not limiting $(T S R<4)$. These results suggest that fungal infection of dead wood during decomposition allows saproxylophagous insects to develop, grow, and reach maturity, and the strength of these limitations might be sex and taxon dependent, especially for $\mathrm{Cu}$ (Fig. 13.6). This analysis, similar to Analysis 1, revealed that even the most nutritious wood is not an adequate food source for its consumers; stoichiometric mismatches persisted even if considerably mitigated via fungal infection of dead wood. Supplementary feeding on fungi may additionally mitigate nutritional limitation. Prolonged development time, which is observed in the beetle species under consideration, may be the result of stoichiometric mismatch and thus limit growth and development as suggested by Filipiak and Weiner (2017a).

The comprehensive analysis of the nutritional limitations experienced over 3-4 years of larval development by Stictoleptura rubra and Chalcophora mariana in dead wood (Filipiak and Weiner 2017a) shows that the life cycles of these beetles are shaped by the importation of $\mathrm{N}, \mathrm{P}, \mathrm{K}, \mathrm{Na}, \mathrm{Mg}, \mathrm{Zn}$, and $\mathrm{Cu}$ by fungi into this nutritionally harsh environment at the start of the decay process. The strategy used by saproxylophages to overcome the nutritional limitations of dead wood involves (1) fungal rearrangements of dead wood stoichiometry during the first years of decay and (2) prolonged growth supported by a low mortality risk. Because the ecological stoichiometry of saproxylophagous insects has not attracted sufficient attention, 
global trends based on a multi-taxa analysis cannot be determined. Additional studies on the limiting elements (e.g., P, N, K, $\mathrm{Na}, \mathrm{Mg}, \mathrm{Zn}$, and $\mathrm{Cu}$ ) and different taxa of dead wood and saproxylophages are needed to elucidate the important interactions between saproxylophages and dead wood as well as the dependencies of saproxylophages on the nutrient dynamics of decomposing wood associated with fungi.

An experimental study of the interactions described above may not be possible because of the long-term and expensive feeding trials required to study growing, wood-eating animals (that require several years of larval development) and to perform long-term terrain studies of decomposing wood. However, the TSR index was developed to identify multiple elements that co-limit the development of an organism and facilitate comparisons between various taxa, habitats, food sources, and life histories (cf. Filipiak and Weiner 2017b). This index may be used as a convenient tool in future studies.

\subsection{Limitations on the Growth and Development of Saproxylophages Are Mitigated During Dead Wood Decomposition via Contributions by Fungi}

The nutritional quality of dead wood changes over the first several years of decomposition, and this is important for the first species of saproxylophagous insects that colonize a dead piece of wood (e.g., the three species of wood-boring beetles presented above). However, the other species that colonize dead wood after this initial stage of decomposition also rely on the nutritional rearrangement of the wood that happens over the first several years of decomposition (Figs. 13.2 and 13.4 suggest how this mechanism may work). As discussed earlier (Sect. 13.6; Fig. 13.2), pure dead wood is too poor nutritionally to be a sufficient source of food for saproxylophagous insects. The nutrients required for insects to properly develop are transported to dead wood by fungi, resulting in a rearrangement of the nutritional composition of the wood during the first few years of decay (Filipiak et al. 2016; Filipiak and Weiner 2017a). Fungal hyphae in dead wood are connected to nutritional patches of organic matter or minerals in the external environment. Rocks can be weathered by fungi and are sources of specific atoms used to build fungal mycelia, and these atoms are further translocated within the ecosystem (Burford et al. 2003; Gadd 2007, 2017a; Gadd et al. 2012; Li et al. 2016). Fungi can consume soil fauna and exchange acquired nutrients for $\mathrm{C}$ from trees (Klironomos and Hart 2001); the acquired nutrients are translocated to dead wood through the fungal mycelium (Stark 1972; Swift et al. 1979; Lodge 1987; Boddy and Watkinson 1995; Dighton 2003, 2007; Cairney 2005; Watkinson et al. 2006; Clinton et al. 2009; Mooshammer et al. 2014). Depending on the size of the adult, saproxylophages can grow, develop, and reach maturity by consuming wood rich in fungal hyphae over the course of several years (Filipiak and Weiner 2017a), and 
during this period, they are able to gather all the building blocks (atoms) required to develop their adult bodies. This prolonged developmental time is feasible because the interior of the dead wood is a safe environment that provides superior climatic conditions, thereby reducing mortality compared with that of insects in the surrounding environment (Walczyńska 2010; Filipiak and Weiner 2017a; Walczyńska and Kapusta 2017).

\subsection{Conclusions and Avenues for Future Research}

The nutrient dynamics of decomposing dead wood have rarely been studied in relation to the specific nutritional needs of saproxylophagous insects. Incorporating an ecological stoichiometric framework could be used to (1) directly relate the nutrient dynamics in dead wood to saproxylophage nutrition; (2) detect specific limitations imposed on the growth and development of insects; (3) identify a set of nutritional elements that co-limit the growth and development of insects; (4) discuss how nutritional limitations influence the growth, reproductive output, survival, fitness, and life histories of dead wood eaters; and (5) better understand wood decomposition rates and standing stocks of wood in different age classes. Points 1-4 could be discussed in relation to the decomposition process as influenced by saproxylophagous insects, which could (6) elucidate the role of dead wood nutrient dynamics in nutrient cycling in ecosystems. Although the nutritional composition of dead wood (including the species-specific concentration of elements in wood) has been studied over the past 50 years, limited information is available on the needs of growing and developing saproxylophagous insects. These insects must extract elemental atoms in the correct proportions to develop and maintain stoichiometric homeostasis. Studies of the elemental compositions of various saproxylophagous insect taxa are needed to identify the nutritional requirements for various elements and relate these needs to the elemental composition and nutrient dynamics of dead wood. Relating the multielemental stoichiometry of saproxylophage bodies to the nutrient dynamics in decaying wood is a prerequisite for understanding the dynamics underlying saproxylophage nutritional balance and identifying nutritional constraints experienced by saproxylophages and potential methods to overcome such constraints. The TSR index could serve as a convenient and easy-to-use tool for analyzing nutritional constraints. The identified limitations should be further studied via feeding experiments, but the long larval development periods of certain species of saproxylophagous insects may render such studies technically impossible.

To date, the application of ecological stoichiometry to the nutrient dynamics of dead wood has led to the following conclusions:

1. The growth and development of dead wood-eating beetles is co-limited by the scarcity of essential elements, such as $\mathrm{N}, \mathrm{P}, \mathrm{K}, \mathrm{Na}, \mathrm{Mg}, \mathrm{Zn}$, and $\mathrm{Cu}$.

2. Fungi use dead wood as a source of energy and nutritionally rearrange it while growing in dead wood during the first 4-5 years of decay. Thus, fungi can fill a 
nutritional niche for dead wood eaters that facilitates insect growth, development, and maturation.

3. In turn, xylophages affect dead wood by fragmenting, shredding, and producing frass, thereby contributing to further wood decomposition and nutrient cycling.

4. Because of the complex ecological interactions among dead wood, fungi, and dead wood eaters, large masses of organic matter in terrestrial ecosystems (wood) are continuously being decomposed in forests. Much remains to be learned about the multielemental co-limitation of saproxylophagous insect growth and development and its role in shaping wood decomposition and nutrient cycling in ecosystems.

Wood stoichiometry and stoichiometric mismatches between wood and saproxylophages might vary with latitude. As was noted in Sect. 13.1, tropical wood seems to be more nutritious than temperate wood (Ragland et al. 1991; Pettersen 1984), but it is not known whether this difference is large enough to be important for saproxylophage nutrition. It is also not known whether the nutritional needs of tropical saproxylophage assemblages differ from those of similar, temperate assemblages. Considering the differences in size between tropical and temperate insects, it may be hypothesized that tropical insects require larger amounts of nutrients to build their bodies. Therefore, a simple comparison of the nutritional quality of dead wood originating from different geographical regions is not sufficient, and such a comparison should be performed that considers the woodsaproxylophage relationship.

It is possible that wood stoichiometry differs between angiosperms and gymnosperms, imposing different stoichiometric mismatches on potential consumers (see Fig. 13.2 and Sect. 13.6). A quick analysis of already available data (Fig. 13.2) has shown that angiosperms indeed impose slightly lower limitations on saproxylophages growth and development than gymnosperms, which results from the generally lower $C$ :other elements ratios in angiosperm wood than in gymnosperm wood. However, even if it is slightly lower, the limiting effect still exists, and it is not known whether the observed difference between angiosperms and gymnosperms is of any importance for saproxylophages (i.e., if the difference might influence their biology). As in the case of geographical differences, elucidating this question requires considering not only the difference between the nutritional value of gymnosperm vs. angiosperm wood but also the nutritional needs of the specific saproxylic assemblages that feed on different types of wood.

Analysis of the data in the literature related to nutrient dynamics in decomposing wood has shown that studies are biased toward temperate regions (mainly Northern Europe) and especially toward the wood of Pinus sylvestris. Additionally, the concentrations of $\mathrm{C}$ in dead wood, which are necessary to calculate stoichiometric mismatches, are rarely considered. Therefore, future studies should focus on sampling more taxonomically and nutritionally diverse data. Furthermore, data on the nutritional needs and stoichiometry of saproxylophages are extremely rare, and without such data, it is impossible to discuss the nutrient dynamics in dead wood, which can be clarified only by considering the nutritional needs of the organisms 
feeding on this wood. Therefore, studies are needed of the nutritional needs and stoichiometry of various saproxylophages inhabiting different wood species that originate from geographically diverse locations.

Acknowledgments I am indebted to Michael Ulyshen, Zuzanna Świątek, and the anonymous reviewers for their constructive comments that greatly improved an earlier version of this manuscript. I also thank Maciej Filipiak for his help creating the graphics. English language editing was performed by American Journal Experts (AJE.com).

This study was supported by the Polish Ministry of Science and Higher Education (Grant No. DS/WBiNoZ/INoŚ/DS 761) and the National Science Centre of Poland (Grant No. DEC 2013/11/N/NZ8/00929).

\section{References}

Aho PE (1974) Distribution, enumeration, and identification of nitrogen-fixing bacteria associated with decay in living White Fir trees. Phytopathology 64:1413-1420. https://doi.org/10.1094/ Phyto-64-1413

Atkinson CL, Capps KA, Rugenski AT, Vanni MJ (2016) Consumer-driven nutrient dynamics in freshwater ecosystems: from individuals to ecosystems. Biol Rev. https://doi.org/10.1111/brv. 12318

Baldrian P (2017) Forest microbiome: diversity, complexity and dynamics. FEMS Microbiol Rev 41:109-130. https://doi.org/10.1093/femsre/fuw040

Becker G (1965) Versuche über den Einfluss von braunfaulepilzen auf Wahl und Ausnutzung der holznährung durch Termiten. Mater Organ 1:95-156

Bignell DE, Roisin Y, Lo N (eds) (2011) Biology of termites: a modern synthesis. Springer Netherlands, Dordrecht

Boddy L, Watkinson SC (1995) Wood decomposition, higher fungi, and their role in nutrient redistribution. Can J Bot 73:1377-1383. https://doi.org/10.1139/b95-400

Bouchard P, Grebennikov VV, Smith ABT, Douglas H (2009) Biodiversity of Coleoptera. In: Foottit RG, Adler PH (eds) Insect biodiversity: science and society. Wiley-Blackwell, Oxford, UK, pp 265-301

Bridges JR (1981) Nitrogen-fixing bacteria associated with bark beetles. Microb Ecol 7:131-137. https://doi.org/10.1007/BF02032495

Burford EP, Fomina M, Gadd GM (2003) Fungal involvement in bioweathering and biotransformation of rocks and minerals. Miner Mag 67:1127-1155. https://doi.org/10.1180/ 0026461036760154

Cairney JWG (2005) Basidiomycete mycelia in forest soils: dimensions, dynamics and roles in nutrient distribution. Mycol Res 109:7-20. https://doi.org/10.1017/S0953756204001753

Čapek P, Kotas P, Manzoni S, Šantrůčková H (2016) Drivers of phosphorus limitation across soil microbial communities. Funct Ecol 30:1705-1713. https://doi.org/10.1111/1365-2435.12650

Chen Y, Forschler BT (2016) Elemental concentrations in the frass of saproxylic insects suggest a role in micronutrient cycling. Ecosphere 7:e01300. https://doi.org/10.1002/ecs2.1300

Cherif M (2012) Biological stoichiometry: the elements at the heart of biological interactions. In: Innocenti A (ed) Stoichiometry and research-the importance of quantity in biomedicine. InTech, Rijeka, pp 357-376

Cherif M, Loreau M (2013) Plant-herbivore-decomposer stoichiometric mismatches and nutrient cycling in ecosystems. Proc Biol Sci 280:20122453. https://doi.org/10.1098/rspb.2012.2453

Cherif M, Faithfull C, Guo J, Meunier CL, Sitters J, Uszko W, Rivera Vasconcelos F (2017) An operational framework for the advancement of a molecule-to-biosphere stoichiometry theory. Front Mar Sci 4:1-16. https://doi.org/10.3389/fmars.2017.00286 
Clinton PW, Buchanan PK, Wilkie JP, Smaill SJ, Kimberley MO (2009) Decomposition of Nothofagus wood in vitro and nutrient mobilization by fungi. Can J For Res 39:2193-2202. https://doi.org/10.1139/X09-134

Clymans W, Conley DJ, Battles JJ, Frings PJ, Koppers MM, Likens GE, Johnson CE (2016) Silica uptake and release in live and decaying biomass in a northern hardwood forest. Ecology 97:3044-3057. https://doi.org/10.1002/ecy.1542

Cohen AC (2003) Insect diets: science and technology. CRC, New York

Cowling EB, Merrill W (1966) Nitrogen in wood and its role in wood deterioration. Can J Bot 44:1539-1554. https://doi.org/10.1139/b66-167

Crotti E, Rizzi A, Chouaia B, Ricci I, Favia G, Alma A, Sacchi L, Bourtzis K, Mandrioli M, Cherif A, Bandi C, Daffonchio D (2010) Acetic acid bacteria, newly emerging symbionts of insects. Appl Environ Microbiol 76:6963-6970. https://doi.org/10.1128/AEM.01336-10

Danger M, Arce Funck JA, Devin S, Heberle J, Felten V (2013) Phosphorus content in detritus controls life-history traits of a detritivore. Funct Ecol 27:807-815. https://doi.org/10.1111/13652435.12079

Denno RF, Fagan WF (2003) Might nitrogen limitation promote omnivory among carnivorous arthropods? Ecology 84:2522-2531. https://doi.org/10.1890/02-0370

Dighton J (2003) Fungi in ecosystem processes, 2nd edn. CRC, New York

Dighton J (2007) Nutrient cycling by saprotrophic fungi in terrestrial habitats. In: Kubicek CP, Druzhinina IS (eds) Environmental and microbial relationships. Springer, Berlin, pp 287-300

Dillon RJ, Dillon VM (2004) The gut bacteria of insects: nonpathogenic interactions. Annu Rev Entomol 49:71-92. https://doi.org/10.1146/annurev.ento.49.061802.123416

Dodds KJ, Graber C, Stephen FM (2001) Facultative intraguild predation by larval Cerambycidae (Coleoptera) on bark beetle larvae (Coleoptera: Scolytidae). Environ Entomol 30:17-22. https:// doi.org/10.1603/0046-225X-30.1.17

Doi H, Cherif M, Iwabuchi T, Katano I, Stegen JC, Striebel M (2010) Integrating elements and energy through the metabolic dependencies of gross growth efficiency and the threshold elemental ratio. Oikos 119:752-765. https://doi.org/10.1111/j.1600-0706.2009.18540.x

Dominik J, Starzyk JR (2004) Owady uszkadzające drewno (Wood damaging insects). PWRiL, Warsaw

Douglas AE (2009) The microbial dimension in insect nutritional ecology. Funct Ecol 23:38-47. https://doi.org/10.1111/j.1365-2435.2008.01442.x

Elser JJ, Hamilton A (2007) Stoichiometry and the new biology: the future is now. PLoS Biol 5: e181. https://doi.org/10.1371/journal.pbio.0050181

Elser JJ, Urabe J (1999) The stoichiometry of consumer-driven nutrient recycling: theory, observations, and consequences. Ecology 80:735-751. https://doi.org/10.1890/0012-9658(1999)080 [0735,TSOCDN]2.0.CO;2

Elser JJ, Dobberfuhl DR, MacKay NA, Schampel JH (1996) Organism size, life history, and N:P stoichiometry. BioScience 46:674-684. https://doi.org/10.2307/1312897

Elser JJ, Sterner RW, Gorokhova E, Fagan WF, Markow TA, Cotner JB, Harrison JF, Hobbie SE, Odell GM, Weider LW (2000a) Biological stoichiometry from genes to ecosystems. Ecol Lett 3:540-550. https://doi.org/10.1046/j.1461-0248.2000.00185.x

Elser JJ, Fagan WF, Denno RF, Dobberfuhl DR, Folarin A, Huberty A, Interlandi S, Kilham SS, McCauley E, Schulz KL, Siemann EH, Sterner RW (2000b) Nutritional constraints in terrestrial and freshwater food webs. Nature 408:578-580. https://doi.org/10.1038/35046058

Evans-White MA, Halvorson HM (2017) Comparing the ecological stoichiometry in green and brown food webs - a review and meta-analysis of freshwater food webs. Front Microbiol 8:1-14. https://doi.org/10.3389/fmicb.2017.01184

Fagan WF, Denno RF (2004) Stoichiometry of actual vs. potential predator-prey interactions: insights into nitrogen limitation for arthropod predators. Ecol Lett 7:876-883. https://doi.org/ 10.1111/j.1461-0248.2004.00641.x 
Fagan WF, Siemann E, Mitter C, Denno RF, Huberty AF, Woods HA, Elser JJ (2002) Nitrogen in insects: implications for trophic complexity and species diversification. Am Nat 160:784-802. https://doi.org/10.1086/343879

Filipiak M (2016) Pollen stoichiometry may influence detrital terrestrial and aquatic food webs. Front Ecol Evol 4:1-8. https://doi.org/10.3389/fevo.2016.00138

Filipiak M, Weiner J (2014) How to make a beetle out of wood: multi-elemental stoichiometry of wood decay, xylophagy and fungivory. PLoS One 9:e115104. https://doi.org/10.1371/journal. pone. 0115104

Filipiak M, Weiner J (2017a) Nutritional dynamics during the development of xylophagous beetles related to changes in the stoichiometry of 11 elements. Physiol Entomol 42:73-84. https://doi. org/10.1111/phen.12168

Filipiak M, Weiner J (2017b) Plant-insect interactions: the role of ecological stoichiometry. Acta Agrobot 70:1-16. https://doi.org/10.5586/aa.1710

Filipiak M, Sobczyk Ł, Weiner J (2016) Fungal transformation of tree stumps into a suitable resource for xylophagous beetles via changes in elemental ratios. Insects 7:13. https://doi.org/ $10.3390 /$ insects 7020013

Filipiak M, Kuszewska K, Asselman M, Denisow B, Stawiarz E, Woyciechowski M, Weiner J (2017) Ecological stoichiometry of the honeybee: pollen diversity and adequate species composition are needed to mitigate limitations imposed on the growth and development of bees by pollen quality. PLoS One 12(8):e0183236. https://doi.org/10.1371/journal.pone.0183236

Foster JR, Lang GE (1982) Decomposition of red spruce and balsam fir boles in the White Mountains of New Hampshire. Can J For Res 12:617-626. https://doi.org/10.1139/x82-094

Fraústo da Silva JJR, Williams RJP (2001) The biological chemistry of the elements. The inorganic chemistry of life, 2nd edn. Oxford University Press, Oxford

Frost PC, Benstead JP, Cross WF, Hillebrand H, Larson JH, Xenopoulos MA, Yoshida T (2006) Threshold elemental ratios of carbon and phosphorus in aquatic consumers. Ecol Lett 9:774-779. https://doi.org/10.1111/j.1461-0248.2006.00919.x

Fukasawa Y, Komagata Y, Kawakami S (2017) Nutrient mobilization by plasmodium of myxomycete Physarum rigidum in deadwood. Fungal Ecol 29:42-44. https://doi.org/10.1016/j. funeco.2017.05.005

Gadd GM (2007) Geomycology: biogeochemical transformations of rocks, minerals, metals and radionuclides by fungi, bioweathering and bioremediation. Mycol Res 111:3-49. https://doi. org/10.1016/j.mycres.2006.12.001

Gadd GM (2017a) The geomycology of elemental cycling and transformations in the environment. Microbiol Spectr 5:1-16. https://doi.org/10.1128/microbiolspec.FUNK-0010-2016

Gadd GM (2017b) Geomycology: geoactive fungal roles in the biosphere. In: John J, White JF (eds) The fungal community. Mycology. CRC, Boca Raton, pp 119-136

Gadd GM, Rhee YJ, Stephenson K, Wei Z (2012) Geomycology: metals, actinides and biominerals. Environ Microbiol Rep 4:270-296. https://doi.org/10.1111/j.1758-2229.2011.00283.x

Galbraith ED, Martiny AC (2015) A simple nutrient-dependence mechanism for predicting the stoichiometry of marine ecosystems. Proc Natl Acad Sci USA 112:8199-8204. https://doi.org/ 10.1073/pnas.1423917112

Gentry JB, Whitford WG (1982) The relationship between wood litter infall and relative abundance and feeding activity of subterranean termites Reticulitermes spp. in three southeastern coastal plain habitats. Oecologia 54:63-67. https://doi.org/10.1007/BF00541109

Gonzalez AL, Dezérald O, Marquet PA, Romero GQ, Srivastaba DS (2017) The multidimensional stoichiometric niche. Front Ecol Evol. https://doi.org/10.3389/fevo.2017.00110

Grier CC (1978) A Tsuga heterophylla-Picea sitchensis ecosystem of coastal Oregon: decomposition and nutrient balances of fallen logs. Can J For Res 8:198-206. https://doi.org/10.1139/x78031

Grove SJ (2002) Saproxylic insect ecology and the sustainable management of forests. Annu Rev Ecol Syst 33:1-23. https://doi.org/10.1146/annurev.ecolsys.33.010802.150507 
Haack RA, Slansky FJ (1987) Nutritional ecology of wood feeding Coleoptera, Lepidoptera and Hymenoptera. In: Rodriguez JG, Slansky F (eds) Nutritional ecology of insects, mites, spiders, and related invertebrates. Wiley, New York, pp 449-486

Hanula JL (1996) Relationship of wood-feeding insects and coarse woody debris. In: Forest Service, Southeastern Forest Experiment Station (eds) Biodiversity and coarse woody debris in Southern Forests. Department of Agriculture, US, Washington, DC, pp 55-81

Harmon ME, Franklin JF, Swanson FJ, Sollins P, Gregory SV, Lattin JD, Anderson NH, Cline SP, Aumen NG, Sedell JR, Lienkaemper GW, Cromack K, Cummins KW (1986) Ecology of coarse woody debris in temperate ecosystems. Adv Ecol Res 15:133-302. https://doi.org/10.1016/ S0065-2504(08)60121-X

Hendee EC (1935) The role of fungi in the diet of the common damp-wood termite, Zootermopsis angusticollis. Hilgardia 9:499-525. https://doi.org/10.3733/hilg.v09n10p499

Hessen DO, Elser JJ, Sterner RW, Urabe J (2013) Ecological stoichiometry: an elementary approach using basic principles. Limnol Oceanogr 58:2219-2236. https://doi.org/10.4319/lo. 2013.58.6.2219

Higashi M, Abe T, Burns TP (1992) Carbon-nitrogen balance and termite ecology. Proc R Soc Lond B Biol Sci 249:303-308. https://doi.org/10.1098/rspb.1992.0119

Jeyasingh PD, Goos JM, Thompson SK, Godwin CM, Cotner JB (2017) Ecological stoichiometry beyond Redfield: an ionomic perspective on elemental homeostasis. Front Microbiol 8:(722). https://doi.org/10.3389/fmicb.2017.00722

Johnson CE, Siccama TG, Denny EG, Koppers MM, Vogt DJ (2014) In situ decomposition of northern hardwood tree boles: decay rates and nutrient dynamics in wood and bark. Can J For Res 44:1515-1524. https://doi.org/10.1139/cjfr-2014-0221

Johnston SR, Boddy L, Weightman AJ (2016) Bacteria in decomposing wood and their interactions with wood-decay fungi. FEMS Microbiol Ecol 92:fiw179. https://doi.org/10.1093/femsec/ fiw 179

Kaspari M, Powers JS (2016) Biogeochemistry and geographical ecology: embracing all twentyfive elements required to build organisms. Am Nat 188(Suppl 1):S62-SS73. https://doi.org/10. $1086 / 687576$

Kaspari M, Yanoviak SP (2008) Biogeography of litter depth in tropical forests: evaluating the phosphorus growth rate hypothesis. Funct Ecol 22:919-923. https://doi.org/10.1111/j.13652435.2008.01447.x

Kaspari M, Bujan J, Weiser MD, Ning D, Michaletz ST, Zhili H, Enquist BJ, Waide RB, Zhou J, Turner BL, Wright SJ (2017a) Biogeochemistry drives diversity in the prokaryotes, fungi, and invertebrates of a Panama forest. Ecology 98:2019-2028. https://doi.org/10.1002/ecy.1895

Kaspari M, Roeder KA, Benson B, Weiser MD, Sanders NJ (2017b) Sodium co-limits and catalyzes macronutrients in a prairie food web. Ecology 98:315-320. https://doi.org/10.1002/ecy.1677

Klausmeier CA, Litchman E, Daufresne T, Levin SA (2008) Phytoplankton stoichiometry. Ecol Res 23:479-485. https://doi.org/10.1007/s11284-008-0470-8

Klironomos JN, Hart MM (2001) Food-web dynamics. animal nitrogen swap for plant carbon. Nature 410:651-652. https://doi.org/10.1038/35070643

Kneip C, Lockhart P, Voss C, Maier UG (2007) Nitrogen fixation in eukaryotes - new models for symbiosis. BMC Evol Biol 7:55. https://doi.org/10.1186/1471-2148-7-55

Köster K, Metslaid M, Engelhart J, Köster E (2015) Dead wood basic density, and the concentration of carbon and nitrogen for main tree species in managed hemiboreal forests. For Ecol Manage 354:35-42. https://doi.org/10.1016/j.foreco.2015.06.039

Kovoor J (1964) Modifications chimiques provoquées par un termitide Microcerotermes edentatus dans du bois de peuplier sain ou partiellement dégradé par des champignons. Bull Biol Fr Belg 98:491-509

Laiho R, Prescott CE (2004) Decay and nutrient dynamics of coarse woody debris in northern coniferous forests: a synthesis. Can J For Res 34:763-777. https://doi.org/10.1139/x03-241

Lambert RL, Lang GE, Reiners WA (1980) Loss of mass and chemical change in decaying boles of a subalpine balsam fir forest. Ecology 61:1460-1473. https://doi.org/10.2307/1939054 
Landvik M, Niemelä P, Roslin T (2016) Mother knows the best mould: an essential role for non-wood dietary components in the life cycle of a saproxylic scarab beetle. Oecologia 182:163-175. https://doi.org/10.1007/s00442-016-3661-y

Lemoine NP, Giery ST, Burkepile DE (2014) Differing nutritional constraints of consumers across ecosystems. Oecologia 174:1367-1376. https://doi.org/10.1007/s00442-013-2860-z

Li Z, Liu L, Chen J, Teng HH (2016) Cellular dissolution at hypha- and spore-mineral interfaces revealing unrecognized mechanisms and scales of fungal weathering. Geology 44:319-322. https://doi.org/10.1130/G37561.1

Lilburn TG, Kim KS, Ostrom NE, Byzek KR, Leadbetter JR, Breznak JA (2001) Nitrogen fixation by symbiotic and free-living spirochetes. Science 292:2495-2498. https://doi.org/10.1126/sci ence.1060281

Liu D, Keiblinger KM, Leitner S, Mentler A, Zechmeister-Boltenstern S (2016) Is there a convergence of deciduous leaf litter stoichiometry, biochemistry and microbial population during decay? Geoderma 272:93-100. https://doi.org/10.1016/j.geoderma.2016.03.005

Ljungdahl LG, Eriksson KE (1985) Ecology of microbial cellulose degradation. In: Marshall KC (ed) Advances in microbial ecology, vol 8. Springer US, New York, NY, pp 237-299

Lodge DJ (1987) Nutrient concentrations, percentage moisture and density of field-collected fungal mycelia. Soil Biol Biochem 19:727-733. https://doi.org/10.1016/0038-0717(87)90055-1

Mansour K (1934) On the digestion of wood by insects. J Exp Biol 11:243-256

Marleau JN, Guichard F, Loreau M (2015) Emergence of nutrient co-limitation through movement in stoichiometric meta-ecosystems. Ecol Lett 18:1163-1173. https://doi.org/10.1111/ele.12495

Martin MM (1983) Cellulose digestion in insects. Comp Biochem Physiol A Physiol 75:313-324. https://doi.org/10.1016/0300-9629(83)90088-9

Martin MM, Jones CG, Bernays EA (1991) The evolution of cellulose digestion in insects [and discussion]. Philos Trans R Soc Lond B Biol Sci 333:281-288. https://doi.org/10.1098/rstb. 1991.0078

Martinson HM, Schneider K, Gilbert J, Hines JE, Hambäck PA, Fagan WF (2008) Detritivory: stoichiometry of a neglected trophic level. Ecol Res 23:487-491. https://doi.org/10.1007/ s11284-008-0471-7

Meerts P (2002) Mineral nutrient concentrations in sapwood and heartwood: a literature review. Ann For Sci 59:713-722. https://doi.org/10.1051/forest:2002059

Meunier CL, Boersma M, El-Sabaawi R, Halvorson HM, Herstoff EM, Van de Waal DB, Vogt RJ, Litchman E (2017) From elements to function: toward unifying ecological stoichiometry and trait-based ecology. Front Environ Sci 5:1-10. https://doi.org/10.3389/fenvs.2017.00018

Moe SJ, Stelzer RS, Forman MR, Harpole WS, Daufresne T, Yoshida T (2005) Recent advances in ecological stoichiometry: insights for population and community ecology. Oikos 109:29-39. https://doi.org/10.1111/j.0030-1299.2005.14056.x

Mooshammer M, Wanek W, Zechmeister-Boltenstern S, Richter A (2014) Stoichiometric imbalances between terrestrial decomposer communities and their resources: mechanisms and implications of microbial adaptations to their resources. Front Microbiol 5:22. https://doi.org/10. 3389/fmicb.2014.00022

Nadeau P, Thibault M, Horgan FG, Michaud J, Gandiaga F, Comeau C, Moreau G (2015) Decaying matters: Coleoptera involved in heterotrophic systems. In: Stack C (ed) Beetles: biodiversity, ecology and role in the environment. Nova Science, New York, pp 123-174

Nardi JB, Mackie RI, Dawson JO (2002) Could microbial symbionts of arthropod guts contribute significantly to nitrogen fixation in terrestrial ecosystems? J Insect Physiol 48:751-763. https:// doi.org/10.1016/S0022-1910(02)00105-1

Palviainen M, Finér L (2015) Decomposition and nutrient release from Norway spruce coarse roots and stumps - a 40-year chronosequence study. For Ecol Manage 358:1-11. https://doi.org/10. 1016/j.foreco.2015.08.036

Palviainen M, Finér L, Laiho R, Shorohova E, Kapitsa E, Vanha-Majamaa I (2010a) Carbon and nitrogen release from decomposing Scots pine, Norway spruce and silver birch stumps. For Ecol Manage 259:390-398. https://doi.org/10.1016/j.foreco.2009.10.034

Palviainen M, Finér L, Laiho R, Shorohova E, Kapitsa E, Vanha-Majamaa I (2010b) Phosphorus and base cation accumulation and release patterns in decomposing Scots pine, Norway spruce 
and silver birch stumps. For Ecol Manage 260:1478-1489. https://doi.org/10.1016/j.foreco. 2010.07.046

Parkin EA (1940) The digestive enzymes of some wood-boring beetle larvae. J Exp Biol 17:364-377

Pearson M, Laiho R, Penttilä T (2017) Decay of Scots pine coarse woody debris in boreal peatland forests: mass loss and nutrient dynamics. For Ecol Manage 401:304-318. https://doi.org/10. 1016/j.foreco.2017.07.021

Pettersen RC (1984) The chemical composition of wood. In: Rowell R (ed) The chemistry of solid wood. American Chemical Society, Washington, DC, pp 57-126

Pinkalski C, Damgaard C, Jensen K-MV, Peng R, Offenberg J (2015) Quantification of ant manure deposition in a tropical agroecosystem: implications for host plant nitrogen acquisition. Ecosystems 18:1373-1382. https://doi.org/10.1007/s10021-015-9906-5

Pinto-Tomás AA, Anderson MA, Suen G, Stevenson DM, Chu FST, Cleland WW, Weimer PJ, Currie CR (2009) Symbiotic nitrogen fixation in the fungus gardens of leaf-cutter ants. Science 326:1120-1123. https://doi.org/10.1126/science.1173036

Pokarzhevskii AD, van Straalen NM, Zaboev DP, Zaitsev AS (2003) Microbial links and element flows in nested detrital food-webs. Pedobiologia 47:213-224. https://doi.org/10.1078/00314056-00185

Preston CM, Trofymow JA, Niu J, Fyfe CA (1998) PMAS-NMR spectroscopy and chemical analysis of coarse woody debris in coastal forests of Vancouver Island. For Ecol Manage 111:51-68. https://doi.org/10.1016/S0378-1127(98)00307-7

Preston CM, Nault JR, Trofymow JA, Smyth C (2009) Chemical changes during 6 years of decomposition of 11 litters in some Canadian Forest sites. Part 1. Elemental composition, tannins, phenolics, and proximate fractions. Ecosystems 12:1053-1077. https://doi.org/10. 1007/s10021-009-9266-0

Purahong W, Wubet T, Lentendu G, Schloter M, Pecyna MJ, Kapturska D, Hofrichter M, Krüger D, Buscot $F$ (2016) Life in leaf litter: novel insights into community dynamics of bacteria and fungi during litter decomposition. Mol Ecol 25:4059-4074. https://doi.org/10.1111/mec.13739

Ragland KW, Aerts DJ, Baker AJ (1991) Properties of wood for combustion analysis. Bioresour Technol 37:161-168. https://doi.org/10.1016/0960-8524(91)90205-X

Reiners WA (1986) Complementary models for ecosystems. Am Nat 127:59-73. https://doi.org/10. 1086/284467

Rinne KT, Rajala T, Peltoniemi K, Chen J, Smolander A, Mäkipää R (2017) Treseder K (ed.) Accumulation rates and sources of external nitrogen in decaying wood in a Norway spruce dominated forest. Funct Ecol 31:530-541. https://doi.org/10.1111/1365-2435.12734

Roskoski JP (1980) Nitrogen fixation in hardwood forests of the northeastern United States. Plant Soil 54:33-44. https://doi.org/10.1007/BF02181997

Sánchez A, Micó E, Galante E, Juárez M (2017) Chemical transformation of quercus wood by Cetonia larvae (Coleoptera: Cetoniidae): an improvement of carbon and nitrogen available in saproxylic environments. Eur J Soil Biol 78:57-65. https://doi.org/10.1016/j.ejsobi.2016.12. 003

Sardans J, Rivas-Ubach A, Peñuelas J (2012) The elemental stoichiometry of aquatic and terrestrial ecosystems and its relationships with organismic lifestyle and ecosystem structure and function: a review and perspectives. Biogeochemistry 111:1-39. doi:https://doi.org/10.1007/s10533-0119640-9

Schade JD, Kyle M, Hobbie SE, Fagan WF, Elser JJ (2003) Stoichiometric tracking of soil nutrients by a desert insect herbivore. Ecol Lett 6:96-101. https://doi.org/10.1046/j.1461-0248.2003. 00409. $\mathrm{x}$

Schneider K, Kay AD, Fagan WF (2010) Adaptation to a limiting environment: the phosphorus content of terrestrial cave arthropods. Ecol Res 25:565-577. https://doi.org/10.1007/s11284009-0686-2

Seibold S, Bässler C, Baldrian P, Thorn S, Müller J, Gossner MM (2014) Wood resource and not fungi attract early-successional saproxylic species of Heteroptera - an experimental approach. Insect Conserv Divers 7:533-542. https://doi.org/10.1111/icad.12076 
Sitters J, Bakker ES, Veldhuis MP, Veen GF, Olde Venterink H, Vanni MJ (2017) The stoichiometry of nutrient release by terrestrial herbivores and its ecosystem consequences. Front Earth Sci 5:1-8. https://doi.org/10.3389/feart.2017.00032

Slansky F, Rodriguez JG (1987) Nutritional ecology of insects, mites, spiders, and related invertebrates. Wiley, New York

Smythe RV, Carter FL, Baxter CC (1971) Influence of wood decay on feeding and survival of the eastern subterranean termite, Reticulitermes flavipes (Isoptera: Rhinotermitidae). Ann Entomol Soc Am 64:59-62. https://doi.org/10.1093/aesa/64.1.59

Soper RS, Olson RE (1963) Survey of biota associated with Monochamus (Coleoptera: Cerambycidae) in Maine. Can Entomol 95:83-95. https://doi.org/10.4039/Ent9583-1

Spano SD, Jurgensen MF, Larsen MJ, Harvey AE (1982) Nitrogen-fixing bacteria in Douglas-fir residue decayed by Fomitopsis pinicola. Plant Soil 68:117-123. https://doi.org/10.1007/ BF02374731

Sperfeld E, Halvorson HM, Malishev M, Clissold FJ, Wagner ND (2016a) Woodstoich III: integrating tools of nutritional geometry and ecological stoichiometry to advance nutrient budgeting and the prediction of consumer-driven nutrient recycling. Oikos 125:1539-1553. https://doi.org/10.1111/oik.03529

Sperfeld E, Raubenheimer D, Wacker A (2016b) Bridging factorial and gradient concepts of resource co-limitation: towards a general framework applied to consumers. Ecol Lett 19:201215. https://doi.org/10.1111/ele.12554

Sperfeld E, Wagner ND, Halvorson HM, Malishev M, Raubenheimer D (2017) Bridging ecological stoichiometry and nutritional geometry with homeostasis concepts and integrative models of organism nutrition. Funct Ecol 31:286-296. https://doi.org/10.1111/1365-2435.12707

Stark N (1972) Nutrient cycling pathways and litter fungi. BioScience 22:355-360. https://doi.org/ $10.2307 / 1296341$

Stenlid J, Penttilä R, Dahlberg A (2008) Wood-decay basidiomycetes in boreal forests: distribution and community development. In: Boddy L, Frankland JC, van West P (eds) British Mycological Society symposia series, vol 28. Academic Press, London, pp 239-262

Sterner RW, Elser JJ (2002) Ecological stoichiometry: the biology of elements from molecules to the biosphere. Princeton University Press, Princeton University, Princeton, NJ

Sterner RW, Hessen DO (1994) Algal nutrient limitation and the nutrition of aquatic herbivores. Annu Rev Ecol Syst 25:1-29. https://doi.org/10.1146/annurev.es.25.110194.000245

Stokland JN, Siitonen J, Jonsson GB (2012) Biodiversity in dead wood. Cambridge University Press, Cambridge

Strukelj M, Brais S, Mazerolle MJ, Paré D, Drapeau P (2017) Decomposition patterns of foliar litter and deadwood in managed and unmanaged stands: a 13-year experiment in boreal mixedwoods. Ecosystems:1-17. https://doi.org/10.1007/s10021-017-0135-y

Swanson EM, Espeset A, Mikati I, Bolduc I, Kulhanek R, White WA, Kenzie S, Snell-Rood EC (2016) Nutrition shapes life-history evolution across species. Proc Biol Sci 283(1834). https:// doi.org/10.1098/rspb.2015.2764

Swift MJ (1977) The ecology of wood decomposition. Sci Prog 64:175-199

Swift MJ, Boddy L (1984) Animal-microbial interactions in wood decomposition. In: Anderson JM, Rayner ADM, Walton DWH (eds) Invertebrate-microbe interactions. Cambridge University Press, Cambridge, pp 89-131

Swift MJ, Heal OW, Anderson JM (1979) Decomposition in terrestrial ecosystems. University of California Press, Berkeley, CA

Täyasu I, Sugimoto A, Wada E, Abe T (1994) Xylophagous termites depending on atmospheric nitrogen. Naturwissenschaften 81:229-231. https://doi.org/10.1007/BF01138550

Thorne BL, Kimsey RB (1983) Attraction of neotropical Nasutitermes termites to carrion. Biotropica 15:295-296. https://doi.org/10.2307/2387656

Ulyshen MD (2015) Insect-mediated nitrogen dynamics in decomposing wood. Ecol Entomol 40:97-112. https://doi.org/10.1111/een.12176

Ulyshen MD (2016) Wood decomposition as influenced by invertebrates. Biol Rev 91:70-85. https://doi.org/10.1111/brv.12158 
Ulyshen MD, Wagner TL (2013) Quantifying arthropod contributions to wood decay. Methods Ecol Evol 4:345-352. https://doi.org/10.1111/2041-210x.12012

Urabe J, Watanabe Y (1992) Possibility of N or P limitation for planktonic cladocerans: an experimental test. Limnol Oceanogr 37:244-251. https://doi.org/10.4319/lo.1992.37.2.0244

Varm A, Kolli BK, Paul J, Saxena S, König H (1994) Lignocellulose degradation by microorganisms from termite hills and termite guts: a survey on the present state of art. FEMS Microbiol Rev 15:9-28. doi:https://doi.org/10.1111/j.1574-6976.1994.tb00120.x

Vega FE, Blackwell M (2005) Insect-fungal associations: ecology and evolution. Oxford University Press, Oxford

Vinet L, Zhedanov A (2010) A “missing” family of classical orthogonal polynomials. Biology of termites: a modern synthesis. In: Bignell D, Roisin Y, Lo N (eds) Biology of termites: a modern synthesis. Springer, Dordrecht, pp 439-475. https://doi.org/10.1007/978-90-481-3977-4_16

Walczyńska A (2010) Is wood safe for its inhabitants? Bull Entomol Res 100(4):461-465. https:// doi.org/10.1017/S0007485309990514

Walczyńska A, Kapusta P (2017) Microclimate buffering of winter temperatures by pine stumps in a temperate forest. Clim Dyn 48(5-6):1953-1961. https://doi.org/10.1007/s00382-016-3184-6

Wallace HR (1953) The ecology of the insect fauna of pine stumps. J Anim Ecol 22:154. https://doi. org/10.2307/1698

Watanabe H, Tokuda G (2010) Cellulolytic systems in insects. Annu Rev Entomol 55:609-632. https://doi.org/10.1146/annurev-ento-112408-085319

Watkinson SC, Bebber D, Darrah P et al (2006) The role of wood decay fungi in the carbon and nitrogen dynamics of the forest floor. In: Gadd GM (ed) Fungi in biogeochemical cycles. Cambridge University Press, Cambridge, pp 151-181

Wells JM, Boddy L (1995) Phosphorus translocation by saprotrophic basidiomycete mycelial cord systems on the floor of a mixed deciduous woodland. Mycol Res 99:977-980. https://doi.org/ 10.1016/S0953-7562(09)80759-4

Wells JM, Hughes C, Boddy L (1990) The fate of soil-derived phosphorus in mycelial cord systems of Phanerochaete Velutina and Phallus impudicus. New Phytol 114:595-606. https://doi.org/ 10.1111/j.1469-8137.1990.tb00430.x

Welti N, Striebel M, Ulseth AJ, Cross WF, DeVilbiss S, Glibert PM, Guo L, Hirst AG, Hood J, Kominoski JS, MacNeill KL, Mehring AS, Welter JR, Hillebrand H (2017) Bridging food webs, ecosystem metabolism, and biogeochemistry using ecological stoichiometry theory. Front Microbiol 8:1298. https://doi.org/10.3389/fmicb.2017.01298

Wilder SM, Jeyasingh PD (2016) Merging elemental and macronutrient approaches for a comprehensive study of energy and nutrient flows. J Anim Ecol 85:1427-1430. https://doi.org/10.1111/ $1365-2656.12573$

Wilson EO (1971) The insect societies. Harvard University Press, Cambridge

Wirtz KW, Kerimoglu O (2016) Autotrophic stoichiometry emerging from optimality and variable co-limitation. Front Ecol Evol 4. https://doi.org/10.3389/fevo.2016.00131

Yuan J, Hou L, Wei X, Shang Z, Cheng F, Zhang S (2017) Decay and nutrient dynamics of coarse woody debris in the Qinling Mountains, China. PLoS One 12:e0175203. https://doi.org/10. 1371/journal.pone.0175203

Zhang J, Elser JJ (2017) Carbon:nitrogen:phosphorus stoichiometry in fungi: a meta-analysis. Front Microbiol 8:1281. https://doi.org/10.3389/fmicb.2017.01281

Zhang C, Jansen M, De Meester L, Stoks R (2016) Energy storage and fecundity explain deviations from ecological stoichiometry predictions under global warming and size-selective predation. J Anim Ecol 85:1431-1441. https://doi.org/10.1111/1365-2656.12531 